\title{
Youth unemployment and personality traits
}

\author{
Silvia Mendolia ${ }^{1 *}$ and lan Walker ${ }^{2}$
}

\author{
* Correspondence: \\ smendoli@uow.edu.au \\ ${ }^{1}$ School of Accounting, Economics \\ and Finance (40.215), Faculty of \\ Business, University of Wollongong, \\ North Wollongong, NSW 2522, \\ Australia \\ Full list of author information is \\ available at the end of the article
}

\begin{abstract}
This paper investigates the relationship between personality traits in adolescence and education and labour market choices. In particular, we investigate the impact of locus of control, effort and diligence, and self-esteem on the risk of youths being unemployed (sometimes referred to as NEET ("Not in Education, Employment or Training"), assuming unconfoundedness. Thus, our focus is on early dropouts from both education and the labour market at age 18-20. We use matching methods to control for a rich set of adolescent and family characteristics by estimating the treatment effects, conditional on unconfoundedness, of multiple personality traits at the same time (Wooldridge, Econometric Analysis of Cross Section and Panel Data, 2010). Finally, we use the methodology proposed by Altonji (J Polit Economy 113:151-184, 2005) that involves making hypotheses about the correlation between the unobservables and observables that determine the outcomes and the unobservables that influence personality. Our results show that individuals that display low effort and diligence, low self-esteem, and external locus of control are estimated to be more likely to drop out of education and employment.

Jel codes: J60, 110
\end{abstract}

Keywords: Personality, NEET, Effort, Locus of control, Self-esteem

\section{Introduction}

The objective of this paper is to analyse the relationship between personality traits, education, and labour market choices. Our study specifically focuses on the role of personality traits in adolescence and early adulthood. In particular, we study the link between traits observed at age 15-16-such as effort and diligence, self-esteem, and locus of control-and the risk of dropping out from education and the labour market at 18-21 years of age. The analysis has policy relevance because several studies have shown that personality traits are stable during adult life (Cobb-Clark and Schurer 2012, 2013) but are relatively malleable over the early lifecycle, even up to the mid 20 's, and can be affected by policy interventions aimed at suppressing harmful traits that affect later life (see Carneiro and Heckman 2003, for a discussion).

The existing literature has analysed the impact of non-cognitive skills on education and labour market outcomes, but has focused on very different indicators, such as years of schooling, college graduation, test scores (Heckman et al. 2006; Coleman and Deleire 2003; Cebi 2007; Mendolia and Walker 2014a), occupational attainment, and wages (Groves 2005; Nyhus and Pons 2005; Cobb-Clark and Tan 2011; Drago 2011; Fletcher 2013). The analysis of the NEET condition is particularly relevant for the British population: in 2013 the proportion of young people in the UK who do not have 
upper secondary education and are neither employed nor in education or training (24\%) has been larger than the OECD and EU average (15\%) by about 10 percentage points (OECD 2014). Figure 1 shows the numbers of young people who are classified as NEET in England from 2000 to 2014 by age range. There is clear seasonality associated with the school leaving cycle, but the numbers of 16-17 year olds who are NEET has been trending downwards. This reflects the rise in post compulsory participation in education driven, in part, by the increase in educational attainment in the high powered tests that take place at the end of grade 11 at age 16 in the UK known as the General Certificate in Secondary Education (GCSE). Attainment in these tests provides entry into the academic track provided by senior high school in grades 11 and 12 . However, there has been only modest growth in attainment in the A-level tests, at age 18, that determines entry to university courses. A-level tests require greater depth of understanding compared to GCSEs, so attainment at this age is more likely to be affected by the non-cognitive skills associated with sustained effort in school. Since the 2008 crisis there has been a steady growth in the NEET rate of 18-25 year olds, reflected in Fig. 1, that reinforced the demographic trends that were already driving the adult NEET rate upwards. (Van Reenen and Petrongolo 2010; Bell and Blanchflower 2010).

Young people who spend time being NEET have poorer short and medium term economic outcomes than those who enter work or who remain in fulltime education (Crawford et al. 2010; Gregg 2001; Mroz and Savage 2006; Machin and Manning 1999). Our analysis is particularly relevant to recent policy changes that have effectively raised the minimum education leaving age from 16 to 18 . This aims to ensure that all young people in England continue in education, or in training leading to an accredited qualification, until the end of the academic year in which they turn 17 (from 2013), and to age 18 (from 2015).

This study contributes to the existing literature on personality traits and labour market outcomes in three ways. First, we analyse the relationship between non-cognitive skills and the probability of youth unemployment associated with dropping out of education and employment (sometimes referred to as being NEET - Not in Education, Employment

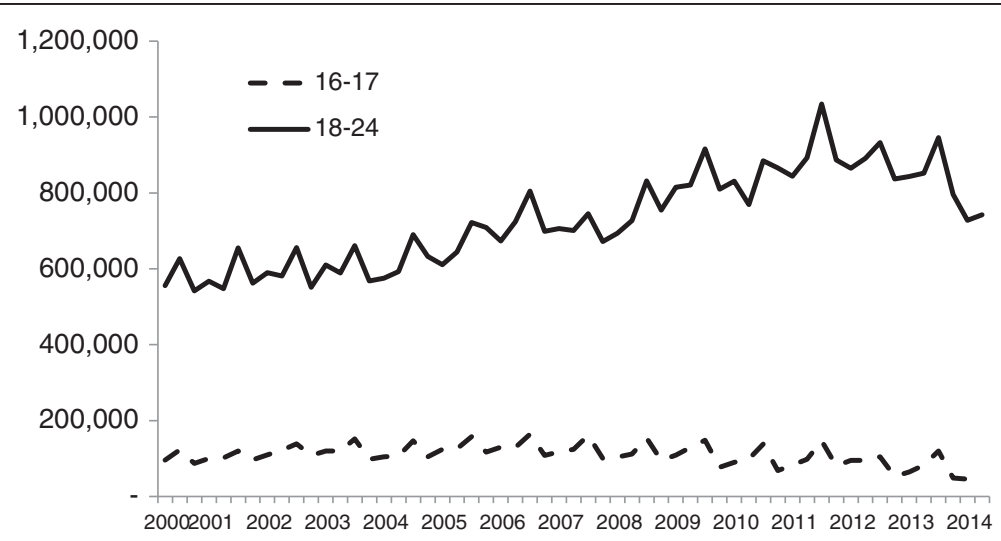

Fig. 1 NEET numbers by age in England: 2000 Q2 - 2014 Q2. Source: Department for education (2014) NEET Quarterly Brief - April to June 2014 
or Training). NEET numbers have been rising in most OECD countries in recent years. In 2011-2012, on average across OECD countries (OECD 2014), 15\% of individuals between the ages of 15 and 29 were neither employed nor in education or training. The NEET rate was, on average, over 15\% in both the United States and Europe.

Secondly, the existing literature relies mostly on relatively dated data (for example, Heckman et al. 2006 and Cebi 2007 use NLSY1979; Coleman and Deleire 2003 uses NELS1988; and, in the UK, Carneiro et al. 2007 uses the NCDS1958 birth cohort) and does not have a specific focus on personality traits in adolescence (Chamorro-Premuzic and Furnham 2003; Delaney et al. 2013). Here we provide evidence from a recent dataset based on a large cohort of English teenagers born in 1990 who were followed for seven years, starting in 2004.

Finally, unlike existing work which considers only one personality trait, our analysis considers the link between multiple traits, as well as interaction between traits, and the risk of dropping out from education and employment by using treatment effects estimators with inverse-probability weighted regression-adjustment (IPWRA) (Wooldridge 2010; Cattaneo, 2010).

Causal inference requires reliable estimation of the missing counterfactual, so we would like to compare treated and control groups, both in terms of of observables and unobservables, that are as similar as possible. Our data does not include any quasiexperimental variation that can be used to address selection on unobservables. But the dataset is rich and allows us to control for many variables that would be unobservable in other datasets. Arguably this richness allows us to tighten the bounds on the relationship between personality traits and NEET status (Dehejia and Wahba 2002). However, a number of authors, including Heckman et al. (1998), Rubin and Thomas (2000), and Rubin (2001), have shown that linear regression augmented by richer covariates can actually increase bias in the estimated treatment effect when the true relationship between the covariate and outcome is even moderately non-linear, especially when there are large differences in the means and variances of the covariates in the treated and control groups. Thus, richness alone is unlikely to reliably reduce selection bias in least squares estimation, but many authors have advocated matching methods based on rich data, which avoids the imposition of linearity, as a practical method to reduce selection bias (Dehejia and Wahba 2002; Goodman and Sianesi 2005; Dehejia, 2005). Nonetheless, matching ultimately relies on observables alone, so, even in rich datasets, caution should be used when interpreting results as causal evidence. Here we use matching methods to investigate the relationship between personality traits and NEET, and we examine the robustness of our results using the methodology proposed by Altonji et al. (2005).

Our results suggest important links between personality traits and youth unemployment, and this is substantiated by our robustness analyses. Statistically significant and economically meaningful relations remain even when we control for having achieved good results in GCSE at age 16, which is regarded as the gold standard of academic achievement at this age in the UK.

\section{Overview of the existing literature}

The relationship between personality traits and education and employment has received increased interest from economists in recent years. Research in personality psychology 
has focused on a widely used taxonomy of traits known as the Big Five (Openness to Experience, Conscientiousness, Extraversion, Agreeableness, and Neuroticism or Emotional Stability). Some of these studies in personality psychology research have demonstrated that personality traits, such as "conscientiousness" and "openess to experience", have a positive correlation with educational outcomes through various mechanisms such as better study behaviours, concentration, and effort. Aspects of emotional stability, such as self-esteem and locus of control, have also been shown to have significant correlation with labour market success. Almlund et al. (2011) provide an excellent review of the major findings from studies conducted in economics and psychology.

A growing body of economics literature has analysed the correlations between personality traits and educational attainment, with a particular focus on high school dropouts. The results generally suggest that traits such as conscientiousness and internal locus of control do affect educational outcomes, even if there is some evidence that the effect of personality traits is different across socio-economic groups (Lundberg 2013). Coleman and Deleire (2003) show that teenagers with internal locus of control are more likely to make educational investments such as completing high school and attending a four-year college. On the other hand, Cebi (2007) replicates the Coleman and Deleire (2003) study using NLSY and suggest that locus of control is not a significant determinant of high school completion and college attendance, once cognitive ability is taken into account. Baron and Cobb-Clark (2010) use data on a recent cohort of Australian youths to show that people with internal locus of control are more likely to complete high school and go to university and that there is very limited evidence that young people growing up in economic disadvantage are more likely to have external locus of control.

A more limited literature in economics has looked at the impact of personality traits on unemployment experience. For example, Caliendo et al. (2015) show that people with greater internal locus of control will look for jobs more intensively and tend to have higher reservation wages. Similarly, a study by McGee and McGee (2011) shows that people with internal locus of control believe that search effort has a higher return. Macmillan (2013) uses the 1970 British Cohort Study and shows that non-cognitive skills play an important role in predicting future spells of unemployment.

Heckman and Rubinstein (2001) study the performance of General Educational Development (GED) recipients and conclude that GED recipients' lower achievements in the labour market and their higher prevalence of criminal or risky behaviours can be attributed to a lack of the "ability to think ahead, persist in tasks and adapt to their environment” (Heckman and Rubinstein 2001, p. 146). Heckman, et al. (2006) use data from the US NLSY1979 and show that locus of control and self-esteem affect schooling decisions, wages, occupational choices, and health-risky behaviours. Heckman and Masterov (2007) and Heckman et al. (2010) analyse the effect of the Perry Preschool programme and emphasise the importance of investing in promoting positive non-cognitive skills from a very early age.

A separate strand of literature in psychology has analysed the role of "grit", which is defined as perseverance with respect to long-term goals, in predicting a variety of success outcomes including educational attainment. This work shows that the continuous and focused application of talent over time is crucial for the achievement of difficult goals 
(Duckworth et al. 2007; Eskreis-Winkler et al. 2014). Similarly, Moffit et al. (2011) use the Dunedin Multidisciplinary Health and Development Study to show that childhood selfcontrol predicts health status, substance use, and criminal behaviour.

In our own analysis we try to establish a connection between several personality traits and the risk of dropping out from education and employment (becoming NEET) for English teenagers. Previous work by Mendolia and Walker (2014a, 2014b) has used a similar methodology (propensity score matching) to investigate the relationship between personality traits and health-risky behaviours and between personality and test scores and subject choice in high school. This study complements and extends the previous work by looking at a different outcome (NEET status) which has a strong relevance for the English population and has important long-lasting consequences for the future lives of adolescents. Here, we also use an additional technique for treatment effect estimation known as inverse probability weighted regression adjustment, IPWRA. This method has been used in several other applications and has the advantage over conventional propensity score methods in that multiple and multi-valued treatments are allowed. This allows us to estimate the relationship between multiple personality traits and NEET status.

The economics literature on the causes of NEET status is very limited, despite a great deal of policy attention and investments to address this phenomenon. Cornaglia et al. (2015) show that poor mental health increases the probability of being NEET by around 3 p.p after controlling for exam performance at age 16. Carneiro et al. (2007) use data from the NCDS to show that social skills have an important role in determining school attainment and labour market outcomes more generally. Britton et al. (2011) discuss different definitions of youth unemployment and NEET and identify a group of characteristics measured at age 14 that may be used to predict the risk of becoming NEET, such as low test scores and poor socio-economic background. High school results appear to be stronger predictors of NEET status than socio-economic status (see also Crawford et al., 2010). However, none of these studies have looked at the importance of personality traits in predicting (and avoiding) NEET status.

\section{Data}

This study uses data from the Longitudinal Study of Young People in England (LSYPE). The data is managed by the UK Department of Education and covers a wide range of topics, including academic achievements, family relationships, attitudes toward school, family and labour market, and some more sensitive or challenging issues, such as risky health behaviours, personal relationships, etc. Young people included in LSYPE were selected to be representative of all young people in England, but at the same time the survey oversampled specific groups (and in particular, young people from a low socioeconomic background). The survey started when these adolescents were in year 9 of school in 2004, at the age of 14, and the records of LSYPE children can be linked to the National Pupil Database (NPD), a pupil-level administrative database of all English pupils including detailed information on pupil test scores and achievements as well as school characteristics. We use this data to collect information about LSYPE children's results in test scores at age 16, which is the minimum school leaving age for this cohort. This occurs at the end of a stage of the national curriculum known as Key Stage 4 and which culminates in national tests known as the General Certificate of Secondary Education (or GCSEs). 
In the second wave of LSYPE (the first wave where information on personality was collected) around 13,500 young people were interviewed. In the first four waves, parents/guardians were also interviewed. Our final sample includes around 9200 observations of children interviewed in wave 2 with non-missing information on NEET status between wave 4 and 7 , personality traits, test scores, and other essential information on the child's birth and family background (the selected observations were not significantly different from the original data in terms of their observable characteristics). The main differences between our sample and the original one were due to individuals with missing observation in their NEET status (because of attrition between wave 2 and the following waves or missing responses to economic activity questions) or in their personality traits (missing responses to one or more questions related to locus of control, effort, and self-esteem).

\section{a. Outcomes}

We investigate the link between personality traits and the chances of dropping out of education but not being employed (i.e., being NEET). In particular, at each wave, the youths in LSYPE are asked to report their main activity. We use this information collected at wave 4, 5, 6, and 7 (age 17-18 to 20-21) and follow the definition of NEET reported in the LSYPE documentation (Department for Education 2011). In particular, a young person is defined as NEET if they are: unemployed (and looking for work), looking after the family, or having a break from study and work (excluding people who are waiting for exam results, have applied for a university course, are waiting to participate in government training programmes, or are travelling). We consider three different NEET outcomes: having been NEET at least once in the 4 waves, having been NEET for two or more years ("core NEET", Britton et al. 2011), and the number of years spent being NEET.

b. Personality traits

Factor analysis has been widely utilised in personality psychology to analyse personality traits and to identify common factors derived from a variety of questions (Cobb-Clark et al. 2014; Piatek and Pinger 2010; and Almlund et al. 2011). LSYPE does not explicitly include information about the "Big Five" personality traits, but it does include a series of questions on effort and diligence, attitudes towards school, long term goals and interests, locus of control, and self-esteem.

Almlund et al. (2011) suggest that self-discipline, competence, and dutifulness are facets of conscientiousness. LSYPE includes four questions on working attitudes (in particular with respect to school work) asked at wave 2 and three questions on perseverance and long term objectives asked at wave 7 (see the Appendix for details). The combination of these questions allows us to construct a measure of personality that includes effort and hard-working attitude and at the same time an indication of the ability to pursue long term objectives and planning for the future-which are likely to be important contributions to "grittiness". The combination of these traits is likely to play a key role in the choices that individuals make with respect to education and labour force status after compulsory education. We follow Duckworth et al. (2007) and combine answers to these question and derive a scale of "effort and diligence", where the maximum score is 4 (very high effort and diligence) and the lowest score is 1 (very low effort and diligence). We also construct a binary indicator and 
define an individual as having "high effort and diligence" if her/his score is in the top quartile of this effort index.

A natural concern is that the three questions on future objectives are only asked at wave 7 (age 20-21) and therefore present a higher risk of reverse causality with respect to the NEET status. For this reason, we run a sensitivity test only using the four questions on effort and work ethics asked at wave 2 and discuss the results in Section 5. The main pattern of results is unchanged, and therefore our preferred specification includes all seven questions, under the assumption that individuals' answers would have been similar if all the questions were asked at age 15-16. Locus of control refers to the extent to which individuals believe that they can affect and control events happening in their own life (Rotter 1966). People with external locus of control believe that their own actions and behaviours do not have an effect on future life outcomes, while individuals with internal locus of control generally believe that life events are mostly caused by their own decisions and behaviours. We measure locus of control using children's responses to six questions (see the Appendix for details). We follow the previous literature in the field (Cobb-Clark et al. 2014; Piatek and Pinger 2010) and use factor analysis to create indices of internal and external locus of control. Children are classified as external if they have a score in the top quartile of the distribution of the external index (Schurer 2014). We also examine the robustness of this definition by classifying children as external if they have a score in the top third or half of the distribution of the external index (Caliendo et al. 2015). Self-esteem refers to an individual emotional evaluation of her/his own value. LSYPE includes two questions on self-esteem (see Appendix for details) asked at waves 2 and 4 . The measure of self-esteem has been calculated following the literature on the topic (see for example Ermisch et al. 2001) and uses all the information available in LSYPE to capture youths' perception of their own value. LSYPE includes a separate measure of mental health different from this self-esteem indicator, which is the General Health Questionnaire (GHQ).

We construct an indicator of low self-esteem equal to 1 if they have placed themselves in the most distressed category for one of the two questions at least once between the two waves (around $27 \%$ of the children in the sample). ${ }^{1}$

c. Other explanatory variables

We estimate three versions of our model, progressively increasing the set of independent variables. All of the variables we control for are, arguably, pre-determined variables-that is, not themselves influenced by personality traits. Our first, most parsimonious model only includes at-birth characteristics such as: birth-weight, whether the child was premature, ethnic background, sex of the child, and family characteristics such as marital status and age of the mother at birth. In the second model we include other family's characteristics (measured at wave 1) such as: child's or parent's disability, maternal education and employment status, single parent family, grandparents' education, family income, and older siblings. In the last version of the model, we also control for test scores at age 16. At the end of Key Stage 4 (from 13 to 16 years old), pupils take the national public examinations known as GCSE in most subjects studied-sometimes in as many as 10 subjects. ${ }^{2}$ GCSE grades range from $A^{*}$ to G. Our independent variable is a binary variable indicating having 5 GCSE passes ( $A^{*}$ to $C$ ) including 
Mathematics and English, which is usually required for students following an academic track for progression beyond age 16.

Table 1 presents the proportion of young people who are NEET, by age, in LSYPE. As expected, the NEET rate increases with age and peaks at age 20. Table 2 presents descriptive statistics on the outcome variables, broken down by personality traits. Individuals who have external locus of control or low self-esteem seem much more likely to end up being NEET (and being in this condition for a longer period of time), while effort and diligence seem to have a protective role. All these differences are statistically significant. Table 3 presents descriptive statistics of other independent variables. Not surprisingly, individuals who are NEET are more likely to come from families with low income and low levels of education.

\section{Estimation}

Our basic specification is first estimated using Ordinary Least Squares to control for observable confounders. The linear model can be written as:

$$
Y_{i}=a+\boldsymbol{P}_{i}^{\prime} \boldsymbol{\beta}+\boldsymbol{X}_{i}^{\prime} \gamma+\varepsilon_{i}
$$

where $Y_{i}$ represents NEET outcome (chances of being NEET at least once between wave 4 and wave 7, having been NEET for at least two years, number of years in NEET condition), $\boldsymbol{P}_{\mathrm{i}}^{\prime}$ is a vector of psychological traits (binary indicators of high effort and diligence, external locus of control, low self-esteem), $X_{\mathrm{i}}^{\prime}$ is a vector of child's and family's characteristics, and $\varepsilon_{i}$ is an idiosyncratic shock.

OLS estimates of $\boldsymbol{\beta}$ will be unbiased if the error term is independent of $\boldsymbol{P}_{\mathrm{i}}$. However, this method is well known to lead to biased estimates of the causal effects because of neglected heterogeneity. Estimation by OLS will be biased if we fail to control for all variables that actually play an important role in determining NEET status (so-called omitted variable bias) or if personality traits are determined with or as a result of previous NEET status, for example, if personality traits and NEET status are jointly determined through the same unobserved process (Cobb-Clark and Schurer 2012).

Since our data does not contain any quasi-experimental variation that might allow us to address the selection on unobservables problem, we rely on observational methods only. We first try to tighten the upper bound provided by the OLS estimation through the estimation of three different specifications of our model, gradually including a more detailed set of independent variables. We are cautious about this method because previous research has shown that the results may become more biased. Moreover, standard OLS regressions may be biased if the true model is not linear in terms of the observed variables and if the relation between personality traits on NEET outcomes is not homogeneous (i.e., the same for all individuals). Both these biases are aggravated if some children fall outside the socalled common support of the observables-that is, if we cannot find in our sample some children with a particular personality trait that are comparable to other children in the

Table 1 Proportion of young people Not in Education, Employment or Training (NEET) by age group in LSYPE

\begin{tabular}{llllll}
\hline & 17 & 18 & 19 & 20 & 21 \\
\hline NEET rate & $5 \%[0.26]$ & $5.4 \%[0.00]$ & $7.3 \%$ & $9 \%[0.00]$ & $8.8 \%[0.01]$ \\
\hline
\end{tabular}

Note: $p$ value for a test of significant difference between NEET rate at different ages and NEET rate at age 19 is reported in brackets 
Table 2 Descriptive statistics of outcome variables by personality traits

\begin{tabular}{lllll}
\hline & $\begin{array}{l}\text { Whole } \\
\text { sample }\end{array}$ & $\begin{array}{l}\text { External locus } \\
\text { of Control }\end{array}$ & Low self-esteem & $\begin{array}{l}\text { High level of effort } \\
\text { and diligence }\end{array}$ \\
\hline $\begin{array}{l}\text { NEET in w4-7 } \\
\text { NEET for 2+ years }\end{array}$ & $0.16(0.37)$ & $0.24(0.42)[0.00]$ & $0.23(0.42)[0.00]$ & $0.08(0.27)[0.00]$ \\
$\begin{array}{l}\text { No. years NEET } \\
0\end{array}$ & $0.04(0.21)$ & $0.09(0.29)[0.00]$ & $0.069(0.025)[0.00]$ & $0.015(0.13)[0.00]$ \\
1 & $0.11(0.31)$ & $0.15(0.36)[0.00]$ & $0.16(0.37)[0.00]$ & $0.06(0.25)[0.00]$ \\
2 & $0.03(0.17)$ & $0.06(0.23)[0.00]$ & $0.04(0.20)[0.00]$ & $0.011(0.10)[0.00]$ \\
3 & $0.01(0.10)$ & $0.02(0.15)[0.00]$ & $0.02(0.13)[0.03]$ & $0.003(0.06)[0.00]$ \\
4 & $0.004(0.06)$ & $0.006(0.08)[0.39]$ & $0.005(0.07)[0.40]$ & $0.001(0.03)[0.02]$ \\
\hline
\end{tabular}

Note: Standard Deviations in brackets. $P$ values for tests of significant differences between NEET rate in the whole sample and NEET rate with a specific personality trait are reported in square brackets

sample without that particular trait. If that is the case, then OLS would be relying on linear extrapolation alone to compare non comparable children. Therefore, we also provide estimates obtained from Propensity Score Matching (PSM) that limits inference to samples where we can find overlap in the distribution of covariates across the treatment and does not rely on any assumptions about the functional form.

As with OLS, PSM relies on conditional independence (or the selection on observables assumption) that requires no selection on unobservables conditional on the observables. The intuition behind this assumption is that, if we have enough information on the observable differences between youths with and without a particular personality trait (the treatment), we can then adjust the raw comparison of those pre-treatment

Table 3 Descriptive statistics of other independent variables by NEET status

\begin{tabular}{llll}
\hline & Never NEET & $\begin{array}{l}\text { Has been NEET at least once } \\
\text { (w4 to w7) }\end{array}$ & $\begin{array}{l}\text { Has been NEET for } \\
2+\text { years }\end{array}$ \\
\hline No. with $5+$ GCSE A $-C$ & 7.4 & 3.5 & 2.4 \\
Income $<£ 11,400$ & $20 \%$ & $31 \%$ & $34 \%$ \\
$£ 11,400<$ income $<£ 31,200$ & $42 \%$ & $50 \%$ & $54 \%$ \\
Income $>£ 31,200$ & $38 \%$ & $19 \%$ & $12 \%$ \\
Mother has university degree & $16 \%$ & $6 \%$ & $5 \%$ \\
Mother has other higher education & $15 \%$ & $10 \%$ & $6 \%$ \\
Mother senior high school graduate & $16 \%$ & $11 \%$ & $9 \%$ \\
Mother junior high school graduate & $30 \%$ & $32 \%$ & $29 \%$ \\
Mother has a lower qualification & $8 \%$ & $13 \%$ & $18 \%$ \\
Mother has other qualification & $3 \%$ & $5 \%$ & $5 \%$ \\
Mother has no qualifications & $12 \%$ & $23 \%$ & $28 \%$ \\
Single mother household at birth & $17 \%$ & $32 \%$ & $33 \%$ \\
Mother $\leq 20$ years old at birth & $5 \%$ & $10 \%$ & $13 \%$ \\
Male & $52 \%$ & $56 \%$ & $55 \%$ \\
Black & $5 \%$ & $4 \%$ & $4 \%$ \\
Asian & $9 \%$ & $6 \%$ & $6 \%$ \\
Mixed & $6 \%$ & $6 \%$ & $5 \%$ \\
Mother unemployed at wave 1 & $1 \%$ & $2 \%$ & $4 \%$ \\
Mother out of labour force at wave 1 & $20 \%$ & $34 \%$ & $42 \%$ \\
\hline & & & \\
\hline
\end{tabular}


differences and obtain unbiased estimates of the relation between personality traits and NEET status. In practice, we assume that personality traits are effectively randomly assigned conditional on a sufficiently large set of observable covariates (Wooldridge 2010). These results are therefore conditional on this strong assumption and should be interpreted accordingly. The credibility of the selection on observables assumption in our context is related to the possibility of capturing all factors that determine NEET status and personality traits. LSYPE provides a very rich source of information, and we make extensive use of it, controlling for a series of factors related to the individual, the family, and the socio-economic environment (see p. 10 for the detailed descriptions of the variables). Although this set of variables is broad, it is possible that we fail to control for all factors that affect the chances of becoming NEET in early adulthood.

Propensity Score Matching attaches weights to the observations in the control group so that the distribution of their observable characteristics is realigned to the treatment group. Moreover, there is some evidence that suggests that it contributes to a reduction in selection bias (see Dehejia and Wahba 2002; Dehejia 2005; Smith and Todd 2004), and PSM has been used in recent papers investigating the determinants of child wellbeing (Ruhm 2008; Berger et al. 2005; Goodman and Sianesi 2005) and the effect of personality traits (Caliendo et al. 2015; Mendolia and Walker 2014a, 2014b). The idea of PSM is to match children with different personality traits (for example, with and without a high level of effort) who are as comparable as possible in all other observable characteristics. More specifically, we first estimate the conditional probability of having a specific personality trait, such as having high levels of effort and diligence, for each child, given our covariates. Then, each treated child is matched with a comparison child (i.e., without the specific personality trait) with the closest propensity score. In other words, estimated propensity scores are used to create a matched control group. Nonmatched individuals are dropped from the analysis. Our analysis is performed using the STATA routine psmatch 2 and appropriate tests have been run in order to compare covariate distributions across our matched groups to ensure that adequate balance has been obtained (Appendix: Table 9). ${ }^{3}$

Furthermore, we estimate the role of multiple personality traits using the STATA teffects ipwra routine and explore two different specifications of the treatments. In the first specification, we consider the different quartiles of the same personality trait (effort and external locus of control) as separate treatments, and therefore we compare youths who are, for example, in the bottom quartile of the effort scale with similar youths who are in higher quartiles of the distribution of the same index. In the second specification, we focus on youths who show "negative personality traits", i.e., low effort, low self-esteem, and external locus of control, and we consider different personality traits (individually and combined in groups of two or three traits) as multiple treatments. We also consider each personality trait and interactions between them as separate treatments in this multiple treatment framework.

In this framework, we are interested in estimating the difference in the outcome with and without treatment, $Y_{1}-Y_{0}$, i.e., the difference in NEET status caused by an individual having one personality trait. As explained in Rosenbaum and Rubin (1983) and Wooldridge (2010), this parameter of interest is the average treatment effect (ATE) defined as $\mathrm{E}\left(Y_{1}-Y_{0}\right)$. This is the expected impact of a particular personality trait on a randomly selected person from the population. The difficulty in estimating ATE is that 
we observe only $Y_{0}$ or $Y_{1}$ (being or not being NEET) for each person. Further, randomisation of personality traits is impossible, and the conditional independence assumption is needed to estimate average treatment effects generally. In other words, the problem that the treatment is not randomised could be overcome by assuming that conditioning on observable covariates makes the outcome conditionally independent of the treatment. Conditional independence allows us to use differences in model-adjusted averages to estimate the ATE.

We use the IPWRA estimator that uses weighted regression coefficients to calculate averages of predicted NEET outcomes for each personality trait, where the weights are the estimated inverse probabilities of having each personality trait. In the first step, the probability of treatment is estimated, and in the second step regression methods are used, with weights provided by the inverse of the probability of treatment (Wooldridge 2010). The weights do not bias the RA (regression-adjustment) estimator if the treatment model is wrongly specified, providing the outcome model is correct. Similarly, the weights correct the RA estimator if the treatment model is correct but the outcome model is wrongly specified. In other words, IPWRA estimators have the so-called double-robustness property (Wooldridge 2007, 2010), so only one of the two equations in the model must be correctly specified to consistently estimate the parameters of interest. The treatment model aims to capture the role of multiple treatments and is therefore estimated using a multinomial logit specification that allows us to analyse different personality traits individually, as well as in combinations of two or three traits. The main advantage of the IPWRA estimator over propensity score matching is that it allows the analysis of multiple treatments at the same time by specifying a multinomial logit model for the treatment and combining regression adjustment and probability weighting to achieve robustness to misspecifications of the parametric models.

Lastly, we examine the robustness of our results using the methodology proposed by Altonji et al. (2005) (AET) that uses the selection on observable traits to provide information about the potential for selection on unobservable characteristics. The AET method requires that there is just one endogenous trait. Thus, we consider trait $P_{k}$ where $k$ indicates external locus of control, high effort, and low self-esteem one at a time. We compare these estimates with conventional propensity score estimate of the same traits, also included sequentially. We follow the methodology proposed in Altonji et al. (2005) and firstly estimate the following bivariate probit model with a constrained correlation coefficient $\rho$, imposing different levels of correlations between the unobserved determinants of personality and the vector of outcomes, $\boldsymbol{Y}$, containing ever NEET and core NEET, in order to verify whether the main estimates are sensitive to these changes:

$$
\begin{aligned}
& \boldsymbol{Y}_{\boldsymbol{k}}=\mathbf{1}\left(a+P_{k}{ }^{\prime} \beta_{k}+\boldsymbol{X}^{\prime} \boldsymbol{\gamma}+\varepsilon>0\right) \\
& \boldsymbol{P}_{\boldsymbol{k}}=\mathbf{1}\left(\mathbf{Z}_{k}{ }^{\prime} \boldsymbol{\theta}_{k}+u^{k}>0\right) \\
& \left(\begin{array}{l}
u \\
\varepsilon
\end{array}\right) \sim N\left(\begin{array}{l}
0 \\
0
\end{array}\right)\left(\begin{array}{ll}
1 & \rho \\
\rho & 1
\end{array}\right)
\end{aligned}
$$

The second part of the AET method consists of using the degree of selection on observable characteristics to set a bound for the degree of selection on unobservables. According to this approach, the part of an outcome (being core NEET or ever NEET) that is related to the observables has the same relationship with personality traits as the part 
related to the unobservables (see Altonji et al. 2005 for the details and Chatterji et al. 2011 and Johnston et al. 2013 for applications of the methodology). Specifically, we use the degree of selection on the observables as a guide to identify the parameter $\rho$. As noted in Altonji et al. (2005), the idea that "selection on the observables is the same as the selection on unobservables" formally implies that:

$$
\frac{\operatorname{Cov}(P, \varepsilon)}{\operatorname{Var}(\varepsilon)}=\frac{\operatorname{Cov}\left(P, X^{\prime} \gamma\right)}{\operatorname{Var}\left(X^{\prime} \gamma\right)}
$$

This condition only holds under the following assumptions: the elements of $X$ are chosen randomly from the full set of variables that determine $Y$; and the number of observed and unobserved factors is large enough so that no element dominates the distribution of the outcome. These assumptions are very strong but, as argued in Altonji et al. (2005), weaker than the standard OLS assumption that $\operatorname{Cov}(X, \varepsilon)=0$. Following Altonji et al. (2005), we present estimates that maximise the likelihood imposing $\rho=\frac{\operatorname{Cov}\left(P^{\prime} \beta, P^{\prime} \gamma\right)}{\operatorname{Var}\left(P^{\prime} \gamma\right)}$ which is equivalent to condition 5 .

In practice, the estimates obtained under this set of assumptions could be treated as a lower bound of the true relationship since we might expect that the relationship between the unobservables and any potentially endogenous personality trait will be weaker than the relationship between the observables and the treatment. For example, as noted in Altonji et al. (2005), the set of covariates $X$ available in the dataset have probably been selected with the intention of reducing bias rather than having been selected at random.

Nevertheless, we acknowledge that all these estimation methods do not address selection on unobservable characteristics but, rather, they allow us to control for a wide variety of observable traits. Therefore, as in all non-experimental studies, caution must be used when interpreting our main results as causal evidence of the impact of personality on NEET.

\section{Results}

The results from the least squares estimation of the relationship between personality traits and chances of dropping out of education and employment are presented in Tables 4, 5, 6, and 7. As already explained, we present results from different specifications of our model, progressively increasing the set of independent variables. As noted in Section 4, all our results rely on conditional independence and therefore should be interpreted with this assumption in mind. Our estimation strategies control for selection on observables, but unfortunately there is no way to fully address the risk of selection on unobservables in our data.

Model 3 includes the same variables of Model 2 but also includes a binary variable indicating whether the youths have achieved 5 or more GCSEs with a grade between $\mathrm{A}^{*}$ and C. Results from this specification are therefore conditioned on GCSE achievements. We believe it is important to show the stability of our main findings from Model 2 when controlling for GCSE achievements because the previous literature has shown that high school attainments are among the main determinants of NEET status. Figures 2 and 3 show the distribution of propensity scores across treatment and control 
Table 4 Personality traits and NEET status - OLS results

\begin{tabular}{|c|c|c|c|c|c|c|c|c|c|}
\hline & \multicolumn{3}{|l|}{ Model 1} & \multicolumn{3}{|l|}{ Model 2} & \multicolumn{3}{|l|}{ Model 3} \\
\hline & $\overline{\text { NEET }}$ & $\begin{array}{l}\text { Core } \\
\text { NEET }\end{array}$ & $\begin{array}{l}\text { No. } \\
\text { years NEET }\end{array}$ & NEET & $\begin{array}{l}\text { Core } \\
\text { NEET }\end{array}$ & $\begin{array}{l}\text { No. } \\
\text { years NEET }\end{array}$ & NEET & $\begin{array}{l}\text { Core } \\
\text { NEET }\end{array}$ & $\begin{array}{l}\text { No. } \\
\text { years NEET }\end{array}$ \\
\hline \multicolumn{10}{|l|}{ OLS } \\
\hline $\begin{array}{l}\text { External locus } \\
\text { of control }\end{array}$ & $\begin{array}{l}0.079 \\
(0.010)^{* * *}\end{array}$ & $\begin{array}{l}0.044 \\
(0.006)^{* * *}\end{array}$ & $\begin{array}{l}0.142 \\
(0.017)^{* * *}\end{array}$ & $\begin{array}{l}0.048 \\
(0.011)^{* * *}\end{array}$ & $\begin{array}{l}0.031 \\
(0.0069)^{* * *}\end{array}$ & $\begin{array}{l}0.092 \\
(0.018)^{* * *}\end{array}$ & $\begin{array}{l}0.018 \\
(0.011)^{* * *}\end{array}$ & $\begin{array}{l}0.020 \\
(0.006)^{* * *}\end{array}$ & $\begin{array}{l}0.047 \\
(0.019)^{* *}\end{array}$ \\
\hline $\begin{array}{l}\text { High effort } \\
\text { and diligence }\end{array}$ & $\begin{array}{l}-0.082 \\
(0.010)^{* * *}\end{array}$ & $\begin{array}{l}-0.035 \\
(0.006)^{* * *}\end{array}$ & $\begin{array}{l}-0.131 \\
(0.017)^{* * *}\end{array}$ & $\begin{array}{l}-0.072 \\
(0.011)^{* * *}\end{array}$ & $\begin{array}{l}-0.032 \\
(0.006)^{* * *}\end{array}$ & $\begin{array}{l}-0.114 \\
(0.018)^{* * *}\end{array}$ & $\begin{array}{l}-0.053 \\
(0.011)^{* * *}\end{array}$ & $\begin{array}{l}-0.026 \\
(0.006)^{* * *}\end{array}$ & $\begin{array}{l}-0.085 \\
(0.018)^{* * *}\end{array}$ \\
\hline Low Self-Esteem & $\begin{array}{l}0.082 \\
(0.010)^{* * *}\end{array}$ & $\begin{array}{l}0.019 \\
(0.006)^{* * *}\end{array}$ & $\begin{array}{l}0.111 \\
(0.016)^{* * *}\end{array}$ & $\begin{array}{l}0.087 \\
(0.011)^{* * *}\end{array}$ & $\begin{array}{l}0.018 \\
(0.006)^{* * *}\end{array}$ & $\begin{array}{l}0.113 \\
(0.018)^{* * *}\end{array}$ & $\begin{array}{l}0.0824 \\
(0.011)^{* * *}\end{array}$ & $\begin{array}{l}0.018 \\
(0.006)^{* * *}\end{array}$ & $\begin{array}{l}0.107 \\
(0.017)^{* * *}\end{array}$ \\
\hline \multirow{2}{*}{$\begin{array}{l}\text { F stat } \\
\text { ( } p \text {-value) }\end{array}$} & 34.42 & 16.50 & 31.38 & 22.88 & 11.32 & 21.78 & 30.06 & 12.47 & 27.22 \\
\hline & 0.000 & 0.000 & 0.000 & 0.000 & 0.000 & 0.000 & 0.000 & 0.000 & 0.000 \\
\hline $\begin{array}{l}\text { N. } \\
\text { observations }\end{array}$ & 6474 & 6474 & 6474 & 5224 & 5224 & 5224 & 5180 & 5180 & 5180 \\
\hline
\end{tabular}

groups. Both graphs show that there is sufficient overlap between the treatment and control groups.

Table 4 presents results from OLS models, where all three personality traits are included in the estimation at the same time. Personality traits play a relevant role on the chances of being NEET and remaining in this condition for a relatively long period of time. In particular, low self-esteem seems to be very detrimental. Note that the mean of having ever been NEET is $15 \%$, while the proportion in the data who have been NEET for two or more years is $4.7 \%$. The results from the estimation using Propensity Score Matching are presented in Table 5 and confirm our OLS findings. Effort and diligence seem to decrease the chances of being NEET by 10 p.p., and almost 7 p.p when we control for GCSE results in Model 3.

Our OLS and PSM results are similar, as shown in Tables 4 and 5. As noticed in Goodman and Sianesi (2005) the distinction between OLS and PSM can be quite a fine one, and it is possible that using a large data-set, as with LSYPE, we have partially overcome the issue of common support. Further, controlling for a wide set of covariates in our OLS model, we might have already reduced the extent of bias in the OLS estimates. Nevertheless, the fact that PSM generally confirms the pattern of OLS findings increases our confidence in the main results.

Table 5 Personality traits and NEET status - PSM Results

\begin{tabular}{|c|c|c|c|c|c|c|c|c|c|}
\hline & \multicolumn{3}{|l|}{ Model 1} & \multicolumn{3}{|l|}{ Model 2} & \multicolumn{3}{|l|}{ Model 3} \\
\hline & NEET & $\begin{array}{l}\text { Core } \\
\text { NEET }\end{array}$ & $\begin{array}{l}\text { No. } \\
\text { years NEET }\end{array}$ & NEET & $\begin{array}{l}\text { Core } \\
\text { NEET }\end{array}$ & $\begin{array}{l}\text { No. } \\
\text { years NEET }\end{array}$ & NEET & $\begin{array}{l}\text { Core } \\
\text { NEET }\end{array}$ & $\begin{array}{l}\text { No. } \\
\text { years NEET }\end{array}$ \\
\hline $\begin{array}{l}\text { External locus } \\
\text { of control }\end{array}$ & $\begin{array}{l}0.089 \\
(0.024)^{* * * *}\end{array}$ & $\begin{array}{l}0.038 \\
(0.014)^{* * *}\end{array}$ & $\begin{array}{l}0.153 \\
(0.039)^{* * *}\end{array}$ & $\begin{array}{l}0.091 \\
(0.017)^{* * *}\end{array}$ & $\begin{array}{l}0.041 \\
(0.011)^{* * *}\end{array}$ & $\begin{array}{l}0.146 \\
(0.029)^{* * *}\end{array}$ & $\begin{array}{l}0.044 \\
(0.018)^{* * *}\end{array}$ & $\begin{array}{l}0.025 \\
(0.011)^{* * *}\end{array}$ & $\begin{array}{l}0.078 \\
(0.031)^{* * *}\end{array}$ \\
\hline $\begin{array}{l}\text { High effort } \\
\text { and diligence }\end{array}$ & $\begin{array}{l}-0.105 \\
(0.025)^{* * *}\end{array}$ & $\begin{array}{l}-0.043 \\
(0.013)^{* * *}\end{array}$ & $\begin{array}{l}-0.162 \\
(0.036)^{* * *}\end{array}$ & $\begin{array}{l}-0.100 \\
(0.013)^{* * *}\end{array}$ & $\begin{array}{l}-0.042 \\
(0.007)^{* * * *}\end{array}$ & $\begin{array}{l}-0.161 \\
(0.021)^{* * *}\end{array}$ & $\begin{array}{l}-0.067 \\
(0.012)^{* * * *}\end{array}$ & $\begin{array}{l}-0.022 \\
(0.006)^{* * *}\end{array}$ & $\begin{array}{l}-0.096 \\
(0.019)\end{array}$ \\
\hline Low Self-Esteem & $\begin{array}{l}0.097 \\
(0.022)^{* * *}\end{array}$ & $\begin{array}{l}0.024 \\
(0.012)^{*}\end{array}$ & $\begin{array}{l}0.140 \\
(0.035)^{* * *}\end{array}$ & $\begin{array}{l}0.094 \\
(0.013)^{* * * *}\end{array}$ & $\begin{array}{l}0.019 \\
(0.008)^{* * * *}\end{array}$ & $\begin{array}{l}0.114 \\
(0.023)^{* * *}\end{array}$ & $\begin{array}{l}0.095 \\
(0.013)^{* * *}\end{array}$ & $\begin{array}{l}0.024 \\
(0.008)^{* * *}\end{array}$ & $\begin{array}{l}0.128 \\
(0.022)^{* * *}\end{array}$ \\
\hline
\end{tabular}

Note: Std errors are in brackets. ${ }^{*}$ indicates that the underlying coefficient is significant at $10 \%$ level, ${ }^{* *}$ at $5 \%$ and ${ }^{* * *}$ at $1 \%$. Additional variables included are listed at p. 9 
Table 6 Estimation of treatment effects with multiple quartiles of personality indexes

\begin{tabular}{|c|c|c|c|c|c|c|}
\hline & \multicolumn{3}{|l|}{ Model 2} & \multicolumn{3}{|l|}{ Model 3} \\
\hline & NEET & Core NEET & $\begin{array}{l}\text { No. years } \\
\text { NEET }\end{array}$ & NEET & Core NEET & $\begin{array}{l}\text { No. years } \\
\text { NEET }\end{array}$ \\
\hline \multicolumn{7}{|c|}{ Effort ( $1^{\text {st }}$ Quartile is omitted) } \\
\hline $2^{\text {nd }}$ Quartile & $\begin{array}{l}-0.074 \\
(0.013)^{* * *}\end{array}$ & $\begin{array}{l}-0.028 \\
(0.008)^{* * *}\end{array}$ & $\begin{array}{l}-0.110 \\
(0.022)^{* * *}\end{array}$ & $\begin{array}{l}-0.049 \\
(0.013)^{* * *}\end{array}$ & $\begin{array}{l}-0.017 \\
(0.007)^{* *}\end{array}$ & $\begin{array}{l}-0.069 \\
(0.021)^{* * *}\end{array}$ \\
\hline $3^{\text {rd }}$ Quartile & $\begin{array}{l}-0.079 \\
(0.012)^{* * *}\end{array}$ & $\begin{array}{l}-0.024 \\
(0.007)^{* * *}\end{array}$ & $\begin{array}{l}-0.118 \\
(0.019)^{* * *}\end{array}$ & $\begin{array}{l}-0.051 \\
(0.011)^{* * *}\end{array}$ & $\begin{array}{l}-0.013 \\
(0.007)^{* *}\end{array}$ & $\begin{array}{l}-0.074 \\
(0.018)^{* * *}\end{array}$ \\
\hline $4^{\text {th }}$ Quartile & $\begin{array}{l}-0.138 \\
(0.011)^{* * *}\end{array}$ & $\begin{array}{l}-0.058 \\
(0.006)^{* * *}\end{array}$ & $\begin{array}{l}-0.219 \\
(0.017)^{* * *}\end{array}$ & $\begin{array}{l}-0.101 \\
(0.011)^{* * *}\end{array}$ & $\begin{array}{l}-0.045 \\
(0.006)^{* * * *}\end{array}$ & $\begin{array}{l}-0.162 \\
(0.017)^{* * *}\end{array}$ \\
\hline \multicolumn{7}{|c|}{ External Locus of Control ( $1^{\text {st }}$ Quartile is omitted) } \\
\hline $2^{\text {nd }}$ Quartile & $0.031(0.013)^{* * *}$ & $0.006(0.007)$ & $0.040(0.019)^{* *}$ & $0.016(0.014)$ & $0.002(0.007)$ & $0.021(0.021)$ \\
\hline $3^{\text {rd }}$ Quartile & $0.037(0.013)^{* *}$ & $0.020(0.007)^{* * *}$ & $0.074(0.021)^{* * *}$ & $0.010(0.013)$ & $0.0128(0.007)$ & $0.035(0.022)$ \\
\hline $4^{\text {th }}$ Quartile & $0.092(0.014)^{* * *}$ & $0.044(0.008)^{* * *}$ & $0.156(0.022)^{* * *}$ & $0.043(0.014)^{* * *}$ & $0.028(0.008)^{* * *}$ & $0.084(0.022)^{* * *}$ \\
\hline
\end{tabular}

Our results on effort and diligence have been examined for robustness by estimating the model only using the four questions on hard working attitude asked at wave 2 and using factor analysis to combine them in an indicator of high work ethics. The results are shown in Appendix: Table 10 and show that individuals with high work ethics (measured only at wave 2) are around 6 p.p less likely to be NEET (4 p.p in the model including GCSE), and results are highly significant. Thus, these findings support our reported results above, which include wave 7 responses as well as wave 2 .

Youths with external locus of control and low self-esteem face higher risks of being NEET and remaining in this condition for a long period of time. Low self-esteem is particularly negative, as the size of the relation is very stable (a 9 p.p rise in the chance of being NEET and a 2 p.p. rise in chance of being core NEET) even when we control for GCSE attainment. The results from the balancing tests for the PSM model are available in Appendix: Table 9.

Table 7 Estimation of treatment effects with multiple treatments

\begin{tabular}{|c|c|c|c|c|c|c|}
\hline & \multicolumn{3}{|l|}{ Model 2} & \multicolumn{3}{|l|}{ Model 3} \\
\hline & NEET & Core NEET & $\begin{array}{l}\text { No. years } \\
\text { NEET }\end{array}$ & NEET & Core NEET & $\begin{array}{l}\text { No. years } \\
\text { NEET }\end{array}$ \\
\hline Low effort and diligence & $\begin{array}{l}0.085 \\
(0.013)^{* * *}\end{array}$ & $\begin{array}{l}0.045 \\
(0.008)^{* * *}\end{array}$ & $\begin{array}{l}0.145 \\
(0.021)^{* * *}\end{array}$ & $\begin{array}{l}0.051 \\
(0.0127)^{* * *}\end{array}$ & $\begin{array}{l}0.032 \\
(0.008)^{* * *}\end{array}$ & $\begin{array}{l}0.093 \\
(0.021)^{* * *}\end{array}$ \\
\hline External LC & $\begin{array}{l}0.047 \\
(0.017)^{* * *}\end{array}$ & $\begin{array}{l}0.016 \\
(0.009)^{*}\end{array}$ & $\begin{array}{l}0.067 \\
(0.027)^{* *}\end{array}$ & $\begin{array}{l}0.015 \\
(0.017)\end{array}$ & $\begin{array}{l}0.004 \\
(0.008)\end{array}$ & $\begin{array}{l}0.018 \\
(0.025)\end{array}$ \\
\hline Low Self-Esteem & $\begin{array}{l}0.083 \\
(0.014)^{* * *}\end{array}$ & $\begin{array}{l}0.027 \\
(0.008)^{* * *}\end{array}$ & $\begin{array}{l}0.121 \\
(0.023)^{* * *}\end{array}$ & $\begin{array}{l}0.074 \\
(0.015)\end{array}$ & $\begin{array}{l}0.025 \\
(0.009)\end{array}$ & $\begin{array}{l}0.108 \\
(0.025)^{* * *}\end{array}$ \\
\hline $\begin{array}{l}\text { Low effort and external } \\
\text { LC }\end{array}$ & $\begin{array}{l}0.128 \\
(0.027)^{* * *}\end{array}$ & $\begin{array}{l}0.068 \\
(0.019)^{* * *}\end{array}$ & $\begin{array}{l}0.222 \\
(0.047)^{* * *}\end{array}$ & $\begin{array}{l}0.090 \\
(0.026)^{* * *}\end{array}$ & $\begin{array}{l}0.045 \\
(0.015)^{* * *}\end{array}$ & $\begin{array}{l}0.149 \\
(0.041)^{* * *}\end{array}$ \\
\hline $\begin{array}{l}\text { Low effort and low self } \\
\text { esteem }\end{array}$ & $\begin{array}{l}0.205 \\
(0.021)^{* * *}\end{array}$ & $\begin{array}{l}0.048 \\
(0.012)^{* * *}\end{array}$ & $\begin{array}{l}0.278 \\
(0.033)^{* * *}\end{array}$ & $\begin{array}{l}0.156 \\
(0.021)^{* * *}\end{array}$ & $\begin{array}{l}0.032 \\
(0.011)^{* * *}\end{array}$ & $\begin{array}{l}0.202 \\
(0.031)^{* * *}\end{array}$ \\
\hline $\begin{array}{l}\text { Low self-est. and external } \\
\text { LC }\end{array}$ & $\begin{array}{l}0.122 \\
(0.028)^{* * *}\end{array}$ & $\begin{array}{l}0.065 \\
(0.018)^{* * *}\end{array}$ & $\begin{array}{l}0.205 \\
(0.046)^{* * *}\end{array}$ & $\begin{array}{l}0.078 \\
(0.023)^{* * *}\end{array}$ & $\begin{array}{l}0.051 \\
(0.016)^{* * *}\end{array}$ & $\begin{array}{l}0.142 \\
(0.040)^{* *}\end{array}$ \\
\hline All 3 traits & $\begin{array}{l}0.209 \\
(0.031)^{* * *}\end{array}$ & $\begin{array}{l}0.068 \\
(0.019)^{* * *}\end{array}$ & $\begin{array}{l}0.314 \\
(0.052)^{* * *}\end{array}$ & $\begin{array}{l}0.151 \\
(0.029)^{* * *}\end{array}$ & $\begin{array}{l}0.050 \\
(0.016)^{* * *}\end{array}$ & $\begin{array}{l}0.225 \\
(0.046)^{* * *}\end{array}$ \\
\hline
\end{tabular}

Note: Standard errors are in parentheses. *indicates that the underlying coefficient is significant at $10 \%$ level, ** at $5 \%$ and ${ }^{* *}$ at $1 \%$. Additional variables included in the analysis are listed at p. 9 


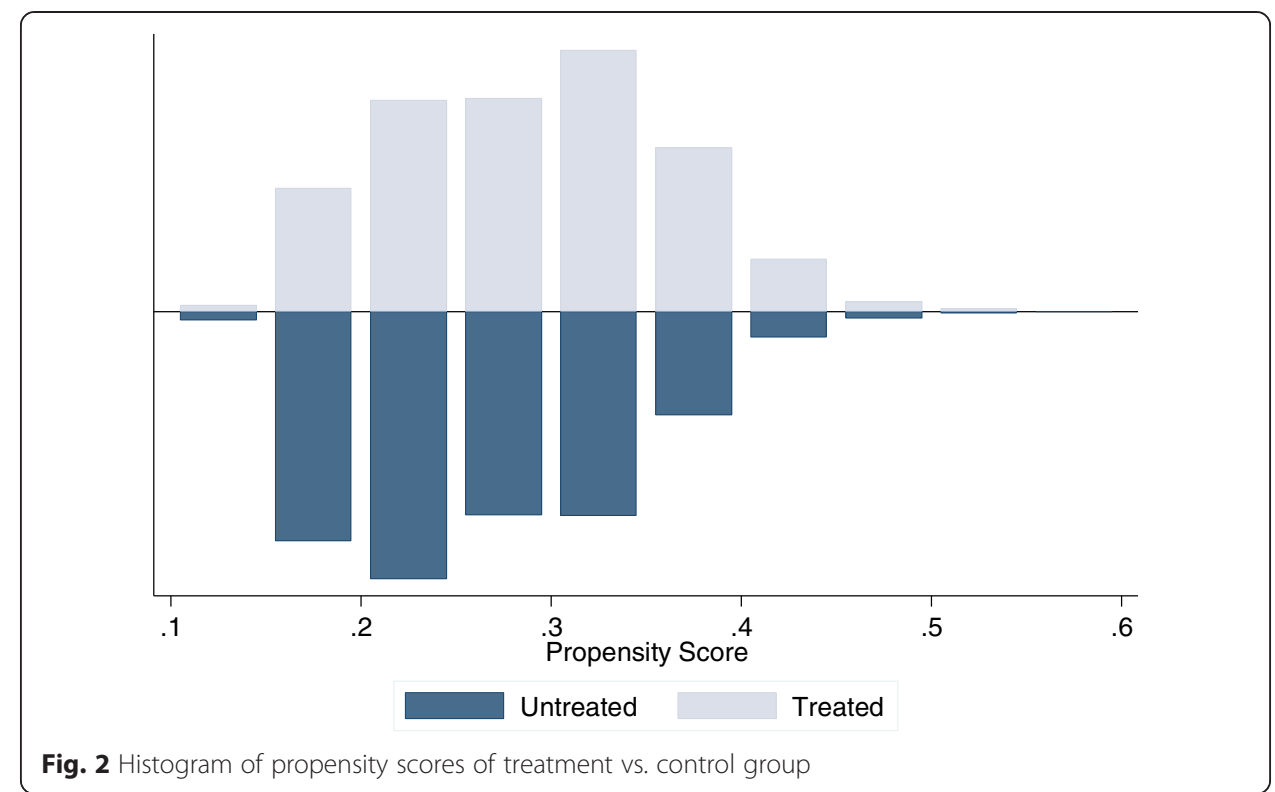

One possible explanation for the negative link between low self-esteem and NEET status is that youths with this trait tend to have a generally negative opinion of themselves and their value. Low self-esteem may have an impact on aspirations and attempts to achieve potential, and this may in turn affect the ability to make decisions about the future and choices about education and labour market participation.

Similarly, individuals with external locus of control tend to think that their choices have less impact on their future, which they believe are mostly driven by luck and external circumstances. As a consequence, these youths are less likely to make constructive decisions about their future and to put substantial effort into achieving their goals.

Lastly, individuals with high levels of effort and diligence are more likely to have higher levels of perseverance towards long term goals and be able to maintain focus on

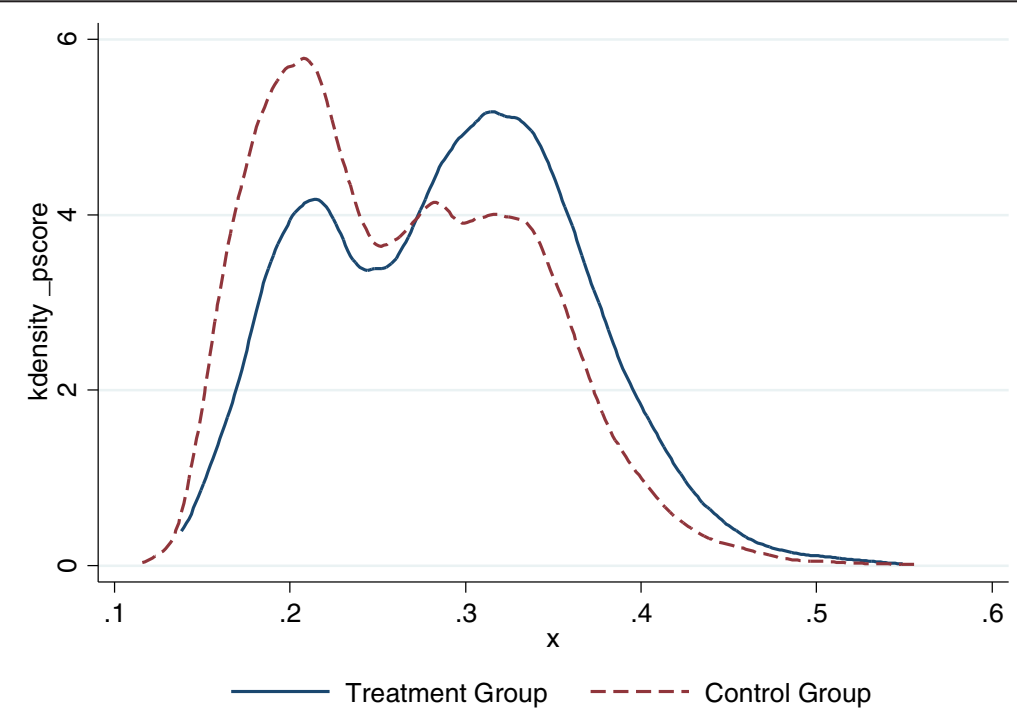

Fig. 3 Kernel graphs of propensity score for treated and control group 
long-term challenges. As already shown by the literature in psychology (see for example Duckworth et al. 2007), perseverance of effort could be even more important than talent to achieve ambitious career goals, and our results confirm the consistent positive relation with reducing the chance of dropping out of education and labour market.

These results are confirmed when we split the sample by gender. Interestingly, effort is positive for both girls and boys, while low self-esteem seems more harmful for boys (results are available in Appendix: Table 11).

Tables 6 and 7 show results from the estimation analysing personality traits as multiple treatments. The estimation of treatment effects is performed by using an inverse-probability weighted regression-adjustment (IPWRA) estimator and multinomial logit techniques to specify the treatment model. In Table 6, we compare youths who are in the bottom quartile of the effort scale (have very low effort) with youths who have higher levels of effort and youths who are in the bottom quartile of external locus of control with those in higher quartiles of the same index. Results confirm previous findings: young people who show very high levels of effort (top quartile) appear less likely to be NEET, while the risk increases steadily for those with low effort and external locus of control (top quartile of the external index).

In Table 7, we focus on youths with low effort, low self-esteem, and external locus of control, and we analyse the combinations of the three personality traits at the same time in a multinomial logit framework. We define an individual as having "low effort and diligence" if her/his score is in the lowest quartile of the effort scale as described in Section 3.2, and low self-esteem is defined, in two questions, as someone who either feels not useful or worthless. For this analysis, we construct a variable called 'personality' that assumes different values depending on the eight possible combinations of the three personality traits:

a. the young person does not show low self-esteem, not low effort and not external locus of control (omitted category);

b. the young person shows low effort and diligence but does not have low self-esteem or external locus of control;

c. the young person shows external locus of control but not low self-esteem and not low effort;

d. the young person shows low self-esteem, but is diligent and does not have external locus of control;

e. the young person shows low effort and external locus of control but not low self-esteem;

f. the young person shows low effort and low self-esteem, but not external locus of control;

g. the young person shows low self-esteem and external locus of control but not low effort;

h. the young person shows all three negative traits-low self-esteem, low effort, and external locus of control.

The results confirm previous OLS and PSM findings. Low effort and diligence together with low self-esteem are particularly detrimental and increase the likelihood of being NEET and remaining in this condition for a long time. The combination of these two 
particular traits and of all three 'negative' traits seems particularly detrimental, and young people who show these characteristics experience a significantly increased likelihood of being NEET. These findings remain when we include achievements in GCSE exams as a control variable in Model 3.

As already explained, these results depend on the validity of the assumptions behind the estimation methods that have been used, especially the conditional independence assumption. Unfortunately, our data does not allow us to exploit any quasiexperimental variation in personality traits, and given the strength of the underlying assumptions, the results should be interpreted cautiously.

Lastly, in Table 8 we present results from the empirical strategy proposed by Altonji et al. (2005), as applied by Chatterji et al. (2011), which does not rely on untestable identifying assumptions. Each estimate in Table 8 is from a bivariate probit of one of each of two dependent variables, and for each of three traits as explanatory variables. The columns impose different degrees of correlation between the unobservable and the respective trait. The first part of the AET method consists in varying the level of correlation between unobservables determining personality traits and NEET outcomes and determining whether the relation with personality is sensitive to these variations. The true level of correlation between the errors is unknown. However, we follow Johnston et al. (2013), and we use the correlations between the outcomes and each specific personality traits in a linear model without other covariates (reported in the first column of Table 8) as a guide to varying $\rho$. For example, it is reasonable to assume that unobserved factors will affect effort and NEET outcomes in opposite directions. The coefficient of high effort in a linear model where we regress the probability of being NEET on it, with no other covariates, is equal to -0.11 and therefore we vary $\rho$ between 0 and -0.15 .

The results presented in Table 8 generally confirm the main previous findings. Effort and diligence seem to decrease the chances of being NEET for at least two years even when increasingly negative levels of correlations are imposed, especially in Model 2. The last column of Table 8 shows results for the second part of the AET method where a bivariate probit model is estimated under the stringent assumption that selection on observables is equal to selection on unobservables. The positive relation between effort and chances of being NEET for at least two years persist when selection on observables is set equal to selection on unobservables.

Similarly, results from the AET test confirm that youths with low self-esteem face increased chances of being NEET and remaining in this condition for at least two years. The results are sensitive to increasing the level of positive correlation between the error terms, but the coefficient of low self-esteem remains positive and significant when selection on observable is set equal to selection on unobservables. Lastly, we vary the level of positive correlation between the error terms in the model estimating the link between external locus of control and NEET status. The results are sensitive to the imposed increasing level of correlation, especially in Model 3 (where we also control for previous GCSE attainments). When selection on observables is set equal to selection on unobservables, the coefficient of external locus of control seems particularly sensitive to high levels of positive correlation $(\rho=0.55)$ and changes sign. In general, the results from the AET method confirm our original findings of significant correlation with personality traits (and in particular high effort and self-esteem) on decisions to drop out of education and from the labour market. 
Table 8 Personality traits on NEET status in Bivariate Probit given different assumptions on the correlations of disturbances (AET Test) - Marginal Effects

\begin{tabular}{|c|c|c|c|c|c|}
\hline $\begin{array}{l}\text { High effort and } \\
\text { diligence - Model } 2\end{array}$ & $\rho=0$ & $\rho=-0.05$ & $\rho=-0.1$ & $\rho=-0.15$ & $\begin{array}{l}\rho \text { set such that select on obs. }=\text { select on } \\
\text { unobs. }\end{array}$ \\
\hline NEET & -0.481 & -0.395 & -0.307 & -0.220 & 0.158 \\
\hline \multirow[t]{2}{*}{-0.11} & $(0.049)^{* * *}$ & $(0.049)^{* * *}$ & $(0.049)^{* * *}$ & $(0.049)^{* * *}$ & $(0.047)^{* *}$ \\
\hline & {$[-0.092]$} & {$[-0.077]$} & {$[-0.062]$} & {$[-0.046]$} & {$[0.037] \mathrm{rho}=-0.29$} \\
\hline Core NEET & -0.614 & -0.527 & -0.438 & -0.349 & -0.133 \\
\hline \multirow[t]{2}{*}{-0.05} & $(0.086)^{* * *}$ & $(0.086)^{* * *}$ & $(0.085)^{* * *}$ & $(0.085)^{* * *}$ & $(0.080)^{*}$ \\
\hline & {$[-0.033]$} & {$[-0.029]$} & {$[-0.026]$} & {$[-0.021]$} & {$[-0.010] \mathrm{rho}=-0.26$} \\
\hline \multicolumn{6}{|c|}{ High effort and diligence - Model 3} \\
\hline NEET & -0.386 & -0.299 & -0.211 & -0.123 & 0.408 \\
\hline \multirow[t]{2}{*}{-0.11} & $(0.052)^{* * *}$ & $(0.051)^{* * *}$ & $(0.052)^{* * *}$ & $(0.052)^{* *}$ & $(0.048)^{* * *}$ \\
\hline & {$[-0.069]$} & {$[-0.055]$} & {$[-0.039]$} & {$[-0.024]$} & {$[0.097] \mathrm{rho}=-0.43$} \\
\hline \multirow[t]{2}{*}{ Core NEET } & -0.532 & -0.443 & -0.353 & -0.262 & 0.169 \\
\hline & $(0.091)^{* * *}$ & $(0.091)^{* * *}$ & $(0.091)^{* * *}$ & $(0.091)^{* * *}$ & $(0.087)^{* * *}$ \\
\hline-0.05 & {$[-0.022]$} & {$[-0.019]$} & {$[-0.016]$} & {$[-0.013]$} & {$[0.011] \mathrm{rho}=-0.36$} \\
\hline Low self-esteem -Model 2 & $\rho=0$ & $\rho=0.05$ & $\rho=0.1$ & $\rho=0.15$ & $\begin{array}{l}\rho \text { set such that select on } \\
\text { obs. = select on unobs. }\end{array}$ \\
\hline NEET & 0.401 & 0.318 & 0.233 & 0.151 & 0.423 \\
\hline \multirow[t]{2}{*}{0.08} & $(0.039)^{* * *}$ & $(0.039)^{* * *}$ & $(0.039)^{* * *}$ & $(0.039)^{* * *}$ & $(0.039)^{* * *}$ \\
\hline & {$[0.098]$} & {$[0.076]$} & {$[0.055]$} & {$[0.035]$} & {$[0.104] \mathrm{rho}=-0.01$} \\
\hline Core NEET & 0.217 & 0.133 & 0.050 & -0.031 & 0.226 \\
\hline \multirow[t]{2}{*}{0.03} & $(0.057)^{* * *}$ & $(0.056)^{* *}$ & $(0.053)$ & $(0.056)$ & $(0.057)^{* * *}$ \\
\hline & {$[0.018]$} & {$[0.011]$} & {$[0.004]$} & {$[-0.002]$} & {$[0.019] \mathrm{rho}=-0.005$} \\
\hline \multicolumn{6}{|l|}{ Low self-esteem - Model 3} \\
\hline NEET & 0.382 & 0.299 & 0.214 & 0.132 & 0.248 \\
\hline 0.08 & $(0.041)^{* * *}$ & $(0.041)^{* * *}$ & $(0.041)^{* * *}$ & $(0.041)^{* * *}$ & $(0.041)^{* * *}$ \\
\hline Core NEET & [0.085] & {$[0.065]$} & {$[0.046]$} & {$[0.028]$} & {$[0.054] \mathrm{rho}=0.08$} \\
\hline \multirow[t]{3}{*}{0.03} & 0.197 & 0.114 & 0.031 & -0.049 & 0.073 \\
\hline & $(0.059)$ & $(0.059)^{*}$ & $(0.059)$ & $(0.059)$ & $(0.059)$ \\
\hline & {$[0.013]$} & {$[0.007]$} & {$[0.001]$} & {$[-0.003]$} & {$[0.004] \mathrm{rho}=0.07$} \\
\hline $\begin{array}{l}\text { External Locus of } \\
\text { Control - Model } 2\end{array}$ & $\rho=0$ & $\rho=0.05$ & $\rho=0.1$ & $\rho=0.15$ & $\begin{array}{l}\rho \text { set such that select on obs. }=\text { select } \\
\text { on unobs. }\end{array}$ \\
\hline NEET & 0.290 & 0.205 & 0.121 & 0.039 & -0.634 \\
\hline \multirow[t]{2}{*}{0.12} & $(0.048)^{* * *}$ & $(0.048)^{* * *}$ & $(0.048)^{* *}$ & $(0.048)$ & $(0.043)^{* * *}$ \\
\hline & {$[0.067]$} & {$[0.046]$} & {$[0.027]$} & {$[0.008]$} & {$[-.126] \mathrm{rho}=0.55$} \\
\hline Core NEET & 0.350 & 0.267 & 0.183 & 0.102 & -0.573 \\
\hline \multirow[t]{2}{*}{0.05} & $(0.067)^{* * *}$ & $(0.067)^{* * *}$ & $(0.067)^{* * *}$ & $(0.066)$ & $(0.059)^{* * *}$ \\
\hline & {$[0.029]$} & {$[0.021]$} & {$[0.014]$} & {$[0.007]$} & {$[-0.043] \mathrm{rho}=0.56$} \\
\hline \multicolumn{6}{|c|}{ External Locus of Control - Model 3} \\
\hline NEET & 0.148 & 0.064 & -0.018 & -0.099 & -0.812 \\
\hline \multirow[t]{2}{*}{0.12} & $(0.051)^{* * *}$ & $(0.051)$ & $(0.051)$ & $(0.051)$ & $(0.044)^{* * *}$ \\
\hline & {$[0.030]$} & {$[0.013]$} & {$[-0.003]$} & {$[-0.019]$} & {$[-0.143]$ rho $=0.59$} \\
\hline Core NEET & 0.228 & 0.145 & 0.0636 & -0.016 & -0.763 \\
\hline \multirow[t]{2}{*}{0.05} & $(0.071)^{* * *}$ & $(0.07)^{* *}$ & $(0.071)$ & $(0.070)$ & $(0.062)^{* * *}$ \\
\hline & {$[0.015]$} & {$[0.009]$} & {$[0.004]$} & {$[-0.00095]$} & {$[-0.047]$ rho $=0.60$} \\
\hline
\end{tabular}

Note: Standard errors are in parentheses. Marginal effects in brackets. ${ }^{*}$ indicates that the underlying coefficient is significant at $10 \%$ level, ${ }^{* *}$ at $5 \%$ and ${ }^{* * *}$ at $1 \%$. Additional variables included in the analysis are listed at $\mathrm{p}$. 9 . Results from an OLS regression of NEET outcomes on personality traits with no additional covariates are reported in the first column in italic 
As shown in Appendix: Table 12, the estimated coefficients of personality traits are higher than those of other important variables, such as maternal education and employment status or growing up in a single parent household. The results from Appendix: Table 12 are consistent with our expectations and with the previous literature on NEET. The most important determinant of NEET status is GCSE attainment. Generally, youths from high income and high education families are less likely to be NEET. Boys face higher risks than girls and so do children who come from single parent households or whose mothers are unemployed or out of the labour force. Ethnic minorities seem less likely to become NEET.

\section{Conclusion and discussion}

This study has analysed the relationship between high effort, low self-esteem, and external locus of control and the risk of dropping out from education and labour market for English youths. We used the Longitudinal Study of Young People in England, which is a rich source of information on English teenagers and can be linked to the National Pupil Database in order to get detailed information on school outcomes from administrative sources. We find that personality traits have a relevant link with the probability of being out of education or employment between the ages of 18 and 21. The size of the relation is notable and is higher than other important variables, such as maternal education or employment status or growing up in a single parent household. As in all non-experimental studies, the results should be interpreted as associations rather than definitive evidence of causal effects, given the impossibility of fully addressing selection on unobservables.

Our analysis is performed using Ordinary Least Squares, Propensity Score Matching, IPWRA, and the methodology proposed by Altonji et al. (2005), which relies on using the selection on observable traits to provide information about the selection on unobservable characteristics. We use the extensive information available in LSYPE and expand our set of independent variables in an attempt to control for a wide set of factors affecting both NEET outcomes and personality traits. Our results are stable over the three different specifications of our model. Further, PSM and treatment effects estimations allow us to compare a group of children who did not have specific personality traits with youths with similar observable characteristics who have those characteristics.

The paper provides further evidence of the positive association between high effort and diligence and long term life outcomes and on the negative relation of low selfesteem and external locus of control. In particular, we show that high effort significantly decreases the chances of dropping out of education or the labour market, while youths with low self-esteem and external locus of control are more likely to experience these conditions.

The main limitation of this study is that all the estimation techniques that we have used allow us to control for a wide variety of observable variables, but nonetheless we are not able to exploit any exogenous variation in personality that could be used to address selection on unobservables. However, LSYPE is a very rich dataset, and we make extensive use of the information available in it, therefore trying to minimise this risk. Our control variables include an extensive set of individual and family characteristics, including several factors that could potentially affect personality traits, such as early life circumstances, family socio-economic status, and education achievements. 
Psychologists have devoted a significant amount of work to understanding the development of personality traits during childhood and adolescence (see for example Carton and Nowicki 1994 or Kulas 1996). However, it is still unclear whether personality traits respond to socio-economic changes in individuals' lives or that the opposite is true (Cobb-Clark and Schurer 2013). An important direction for future work in this area would be to analyse the development of personality traits, with particular attention to life events, early circumstances, and potential unobserved characteristics. Furthermore, self-reports are widely used to assess individual personality traits, and this presents some methodological challenges, such as the so-called Reference Group Effect-the tendency of individuals to self-report psychological issues not in absolute levels, but rather relative to a significant comparison group (Crede et al. 2010; Heine et al. 2008).

A variety of interventions have been suggested that exploit the early malleability of personality to improve long term outcomes. The World Bank has recently promoted the STEP Skills Measurement Program in collaboration with Angela Duckworth and other researchers in the field of psychology with the objective of improving ways to measure and analyse the importance of socio-emotional skills among youth and adults. Recent research in the area has confirmed the positive effect of interventions aimed at teaching school children the importance of effort, perseverance, and motivation to increase school results, especially for disadvantaged children (Duckworth et al. 2013).

A UK example of a personality-targeted intervention is SEAL (Social and Emotional Aspects of Learning), a voluntary programme designed to develop the social and emotional skills of all school pupils in the areas of self-awareness, managing feelings, empathy, motivation and social skills. SEAL is currently being implemented in around 90\% of primary schools and 70\% of secondary schools (Hallam et al. 2006). Very recently, following a review of the literature (Gutman and Schoon 2013), the Department of Education has embraced the idea that such non-cognitive skills might have important effects. For example, the Department has recently run a competition whereby schools outline their own experiences with ad hoc initiatives.

We believe that our analysis shows some potential benefits of programmes focused on suppressing harmful traits (such as low self-esteem or external locus of control) and promoting positive attitudes, such as perseverance towards long term goals, determination, and motivation. Our results suggest that there is a potential for policies that exploit the association between positive non-cognitive traits and achievements in early adulthood-outcomes that are important determinants of long run living standards.

\section{Endnotes}

${ }^{1}$ Alternative/more restrictive indicators of low self-esteem were constructed to test the robustness of our estimates, and results were very similar to the ones presented.

${ }^{2}$ Results are unchanged if we drop the youths taking less than 5 GCSEs (the weakest students) from our sample.

${ }^{3}$ Our approach is similar to Goodman and Sianesi (2005) and we use propensity score matching with the nearest neighbour method with replacement (as it has 
been shown to reduce bias relative to matching without replacement, see Dehejia and Wahba, 2002) and then used the common option so that off-support observations are automatically dropped. Similar results were obtained with other matching methods.

\section{Appendix}

\section{Effort and diligence- Questions in LSYPE}

1. Doing well at school means a lot to me (wave 2)

2. At school, I work as hard as I can (wave 2)

3. Working hard at school now will help me to get on later in life (wave 2)

4. If you work hard at something, you will usually succeed (wave 2)

5. Studying to get a qualification is important to me (wave 7)

6. Having a job that leads somewhere is important (wave 7)

7. I don't really think much about what I might be doing in a few years (wave 7)

Possible answers: Strongly agree, Agree, Disagree, Strongly disagree. The effort and diligence scale is calculated following Duckworth et al. (2007) as follows:

For questions $1,2,3,4,5,6$, we assign the following points: $1=$ strongly disagree, 2 = disagree, 3 = agree, 4 = strongly agree

For question 7, we assign the following points: 1 = strongly agree, 2 = agree, 3 = disagree, $4=$ strongly disagree

Then, we add up all the points and divide by 7 . The maximum score on the scale is 4 (very high effort and diligence) and the lowest score on the scale is 1 (very low effort and diligence).

\section{Locus of control - Questions in LSYPE (wave 2)}

1. I can pretty much decide what happens in my life

2. If someone is not a success in life, it is usually his fault

3. How well you get in this world is mostly a matter of luck

4. Even if I do well at school, I will have a hard time

5. People like me do not have much of a chance

6. If you work hard at something, you will usually succeed

Possible answers: Strongly agree, Agree, Disagree, Strongly disagree

\section{Self-esteem - Questions in LSYPE (repeated at wave 2 and wave 4)}

1. How useful you have felt recently?

2. How much you have been thinking of yourself as a worthless person recently?

Possible answers: Not at all, No more than usual, Rather more than usual, Much more than usual. 
Table 9 Balance tests for propensity score matching (High effort and diligence and NEET status- Model 3)

\begin{tabular}{|c|c|c|c|c|c|c|}
\hline Variable & $\begin{array}{l}\text { Mean - } \\
\text { Treated }\end{array}$ & $\begin{array}{l}\text { Mean } \\
\text { Control }\end{array}$ & $\begin{array}{l}\% \\
\text { Bias }\end{array}$ & $\begin{array}{l}\% \text { Fall } \\
\text { in Bias }\end{array}$ & $\mathrm{t}$ & $p$ \\
\hline Has $5+$ GCSE with grade $A^{*}-C$ & .6748 & .68997 & -3.1 & 91.3 & -0.99 & 0.322 \\
\hline $\mathrm{HH}$ yearly income $>31,200 £$ & 0.35339 & .36043 & -1.5 & 62.2 & -0.45 & 0.655 \\
\hline $\mathrm{HH}$ yearly income betw. $11,400 £$ and $31,200 £$ & .42493 & .40163 & 4.7 & 5.6 & 1.44 & 0.151 \\
\hline Birth weight & 3.2889 & 3.2976 & -1.5 & 83.5 & -0.45 & 0.651 \\
\hline Premature birth & .10298 & .1084 & -1.8 & -143.1 & -0.54 & 0.592 \\
\hline Has older siblings & .8065 & .79675 & 0.9 & 89.8 & 0.29 & 0.772 \\
\hline Grandparents went to university & .09973 & .1019 & -0.7 & 84.9 & -0.22 & 0.827 \\
\hline Child has disabilty & .12846 & .129 & -0.2 & 96.7 & -0.05 & 0.961 \\
\hline Main parent has disability & .20054 & .21138 & -2.7 & -35.4 & -0.81 & 0.416 \\
\hline Mother has a university degree & .15501 & .15447 & 0.2 & 98.0 & 0.05 & 0.964 \\
\hline Mother has other higher education & 0.15014 & .17019 & -5.7 & -221.6 & -1.66 & 0.097 \\
\hline Mother senior high school graduate & .1355 & .12466 & 3.1 & 24.5 & 0.98 & 0.328 \\
\hline Mother junior high school graduate & .29485 & .29973 & -1.1 & 57.3 & -0.32 & 0.746 \\
\hline Mother has qualifications level 1 or below & .08618 & .07425 & 4.2 & -78.1 & 1.33 & 0.183 \\
\hline Mother has other qualification & .02764 & .03035 & -1.6 & -59.7 & -0.49 & 0.624 \\
\hline Male & .44878 & .42873 & 4.0 & 75.2 & 1.23 & 0.220 \\
\hline Single parent at birth & .19675 & .20108 & -1.1 & 60.1 & -0.33 & 0.742 \\
\hline Mother younger than 20 at birth & .05854 & .05095 & 3.2 & -218.3 & 1.01 & 0.311 \\
\hline Black & 08943 & .06992 & 8.1 & 65.1 & 2.19 & 0.029 \\
\hline Asian & .15014 & .15989 & -3.1 & 87.1 & -0.82 & 0.413 \\
\hline Mixed & .06721 & .0607 & 2.6 & -26.0 & 0.81 & 0.420 \\
\hline Mother was unemployed at wave 1 & .01138 & .01084 & 0.5 & -3014.5 & 0.16 & 0.875 \\
\hline Mother was out of the labour force at wave 1 & .24444 & .24065 & 0.9 & 59.4 & 0.27 & 0.788 \\
\hline Single mother at wave 1 & .19512 & .18482 & 2.5 & 58.8 & 0.80 & 0.425 \\
\hline
\end{tabular}

Table 10 Effort and diligence (measured at wave 2 only) and NEET status

\begin{tabular}{|c|c|c|c|c|c|c|}
\hline & \multicolumn{3}{|l|}{ Model 2} & \multicolumn{3}{|l|}{ Model 3} \\
\hline & NEET & Core NEET & No. years NEET & NEET & Core NEET & No. years NEET \\
\hline $\begin{array}{l}\text { Effort } \\
\text { (at wave 2) }\end{array}$ & $-0.056(0.014)^{* * *}$ & $-0012(0.007)^{*}$ & $-0.070(0.023)^{* * * *}$ & $-0.034(0.014)^{* * *}$ & $-0.014(0.008)^{*}$ & $-0.052(0.023)^{* * *}$ \\
\hline
\end{tabular}

Note: Standard errors are in brackets. *indicates that the underlying coefficient is significant at $10 \%$ level, ** at $5 \%$ and ***at $1 \%$. Additional variables included are listed at p.9 
Table 11 Effect of personality traits on NEET status - PSM Estimation Results by gender

\begin{tabular}{|c|c|c|c|c|c|c|}
\hline & \multicolumn{3}{|l|}{ Model 2} & \multicolumn{3}{|l|}{ Model 3} \\
\hline & NEET & Core NEET & $\begin{array}{l}\text { No. years } \\
\text { NEET }\end{array}$ & NEET & Core NEET & $\begin{array}{l}\text { No. years } \\
\text { NEET }\end{array}$ \\
\hline \multicolumn{7}{|l|}{ Girls } \\
\hline $\begin{array}{l}\text { External locus of } \\
\text { Control }\end{array}$ & $\begin{array}{l}0.079 \\
(0.025)^{* *}\end{array}$ & $\begin{array}{l}0.043 \\
(0.015)^{* *}\end{array}$ & $\begin{array}{l}0.128 \\
(0.043)^{* *}\end{array}$ & $\begin{array}{l}0.052 \\
(0.027)^{* *}\end{array}$ & $\begin{array}{l}0.033 \\
(0.016)^{* *}\end{array}$ & $\begin{array}{l}0.100 \\
(0.45)^{* *}\end{array}$ \\
\hline $\begin{array}{l}\text { High effort and } \\
\text { diligence }\end{array}$ & $\begin{array}{l}-0.092 \\
(0.017)^{* * *}\end{array}$ & $\begin{array}{l}-0.035 \\
(0.009)^{* * *}\end{array}$ & $\begin{array}{l}-0.150 \\
(0.028)^{* * *}\end{array}$ & $\begin{array}{l}-0.082 \\
(0.017)^{* * *}\end{array}$ & $\begin{array}{l}-0.022 \\
(0.008)^{* * *}\end{array}$ & $\begin{array}{l}-0.118 \\
(0.026)^{* * *}\end{array}$ \\
\hline Low Self-Esteem & $\begin{array}{l}0.102 \\
(0.017)^{* *}\end{array}$ & $\begin{array}{l}0.0251 \\
(0.010)^{* *}\end{array}$ & $\begin{array}{l}0.134 \\
(0.028)^{* * *}\end{array}$ & $\begin{array}{l}0.0763 \\
(0.017)^{* *}\end{array}$ & $\begin{array}{l}0.011 \\
(0.010)\end{array}$ & $\begin{array}{l}.096 \\
(0.028)^{* * *}\end{array}$ \\
\hline \multicolumn{7}{|l|}{ Boys } \\
\hline $\begin{array}{l}\text { External locus of } \\
\text { Control }\end{array}$ & $\begin{array}{l}0.069 \\
(0.024)^{* * * *}\end{array}$ & $\begin{array}{l}0.049 \\
(0.014)^{* * *}\end{array}$ & $\begin{array}{l}0.138 \\
(0.040)^{* * *}\end{array}$ & $\begin{array}{l}0.025 \\
(0.026)\end{array}$ & $\begin{array}{l}0.019 \\
(0.016)\end{array}$ & $\begin{array}{l}0.042 \\
(0.045)\end{array}$ \\
\hline $\begin{array}{l}\text { High effort and } \\
\text { diligence }\end{array}$ & $\begin{array}{l}-0.080 \\
(0.019)^{* * * *}\end{array}$ & $\begin{array}{l}-0.039 \\
(0.011)^{* * * *}\end{array}$ & $\begin{array}{l}-0.132 \\
(0.031)^{* * * *}\end{array}$ & $\begin{array}{l}-0.068 \\
(0.019)^{* * * *}\end{array}$ & $\begin{array}{l}-0.029 \\
(0.009)^{* * * *}\end{array}$ & $\begin{array}{l}-0.106 \\
(0.029)^{* * *}\end{array}$ \\
\hline $\begin{array}{l}\text { Low Self- } \\
\text { Esteem }\end{array}$ & $\begin{array}{l}0.107 \\
(0.021)^{* * *}\end{array}$ & $\begin{array}{l}0.044 \\
(0.013)^{* * *}\end{array}$ & $\begin{array}{l}0.176 \\
(0.034)^{* * *}\end{array}$ & $\begin{array}{l}0.127 \\
(0.021)^{* * *}\end{array}$ & $\begin{array}{l}0.040 \\
(0.0128)^{* * *}\end{array}$ & $\begin{array}{l}0.193 \\
(0.034)^{* * *}\end{array}$ \\
\hline F stat ( $p$-value) & & & & & & \\
\hline
\end{tabular}

Note: Std errors are in brackets. ${ }^{*}$ indicates that the underlying coefficient is significant at $10 \%$ level, ${ }^{* *}$ at $5 \%$ and ${ }^{* * *}$ at $1 \%$. Additional variables included are listed at p. 12 
Table 12 Effect of other independent variables on NEET Status and subjects' choice - OLS Results from Model 3

\begin{tabular}{|c|c|c|c|}
\hline & NEET & Core NEET & NEET Years \\
\hline Has 5+ GCSE with grade $A^{*}-C$ & $-0.155(0.011)^{* * *}$ & $-0.049(0.006)^{* * *}$ & $-0.230(0.017)^{* * * *}$ \\
\hline $\mathrm{HH}$ income $>31,200 £$ & $-0.031(0.015)^{* *}$ & $-0.011(0.009)$ & $-0.041(0.024)^{*}$ \\
\hline Income betw. 11,400£ - 31,200£ & $-0.009(0.013)$ & $0.001(0.008)$ & $-0.003(0.021)$ \\
\hline Birth weight & $-0.008(0.009)$ & $-0.001(0.006)$ & $-0.021(0.015)$ \\
\hline Premature birth & $-0.033(0.017)^{*}$ & $-0.006(0.010)$ & $-0.050(0.028)^{*}$ \\
\hline Has older siblings & $0.025(0.005)^{* * *}$ & $0.008(0.003)^{* * *}$ & $0.037(0.008)^{* * * *}$ \\
\hline Grandparents went to university & $-0.010(0.017)$ & $-0.006(0.010)$ & $-0.018(0.027)$ \\
\hline Child has disabilty & $0.024(0.014)^{*}$ & $0.002(0.008)$ & $0.032(0.022)$ \\
\hline Main parent has disability & $0.022(0.012)^{*}$ & $-0.002(0.007)$ & $0.013(0.020)$ \\
\hline Mother -University degree & $-0.046(0.020)^{* *}$ & $-0.021(0.012)^{*}$ & $-0.087(0.032)^{* * *}$ \\
\hline Mother - Other Higher Education & $-0.047(0.019)^{* *}$ & $-0.034(0.011)^{* * *}$ & $-0.105(0.031)^{* * *}$ \\
\hline Mother senior high school gr. & $-0.057(0.018)^{* * *}$ & $-0.031(0.011)^{* * *}$ & $-0.107(0.030)^{* * *}$ \\
\hline Mother junior high school gr. & $-0.028(0.016)^{*}$ & $-0.023(0.010)^{* *}$ & $-0.066(0.026)^{* *}$ \\
\hline Mother has low qualification & $-0.007(0.020)$ & $0.006(0.012)$ & $-0.009(0.033)$ \\
\hline Mother has other qualification & $-0.002(0.030)$ & $-0.015(0.018)$ & $-0.032(0.048)$ \\
\hline Male & $0.022(0.010)^{* *}$ & $0.002(0.006)$ & $0.026(0.016)^{*}$ \\
\hline Single parent at birth & $0.050(0.013)^{* * *}$ & $0.008(0.008)$ & $0.060(0.022)^{* * *}$ \\
\hline Mother younger than 20 at birth & $0.027(0.021)$ & $0.022(0.013)^{*}$ & $0.051(0.034)$ \\
\hline Black & $-0.054(0.022)^{* *}$ & $-0.016(0.013)$ & $-0.074(0.036)^{* *}$ \\
\hline Asian & $-0.071(0.018)^{* * *}$ & $-0.027(0.011)^{* *}$ & $-0.108(0.029)^{* * *}$ \\
\hline Mixed & $-0.019(0.020)$ & $-0.013(0.012)$ & $-0.048(0.033)$ \\
\hline Mother unemployed at wave 1 & $0.011(0.044)$ & $0.101(0.027)^{* * * *}$ & $0.155(0.072)^{* *}$ \\
\hline Mother out of the labour force at Wave 1 & $0.041(0.012)^{* * *}$ & $0.026(0.007)^{* * *}$ & $0.084(0.020)^{* * *}$ \\
\hline Single mother at wave 1 & $0.032(0.014)^{* *}$ & $0.017(0.008)^{* *}$ & $0.057(0.022)^{* * *}$ \\
\hline Constant & $0.246(0.037)^{* * *}$ & $0.080(0.022)^{* * *}$ & $0.402(0.060)^{* * *}$ \\
\hline$R^{2}$ & 0.14 & 0.06 & 0.12 \\
\hline N & 5180 & 5180 & 5180 \\
\hline
\end{tabular}

Note: Standard errors are in brackets. *indicates that the underlying coefficient is significant at $10 \%$ level, ${ }^{* *}$ at $5 \%$ and ${ }^{* * *}$ at $1 \%$

\section{Competing interests}

The IZA Journal of Labor Economics is committed to the IZA Guiding Principles of Research Integrity. Both authors declare that they have observed these principles.

\section{Acknowledgements}

We thank the participants of the 2015 SOLE/EALE World Congress in Montreal, and of the 2015 IHEA Congress in Milan for their suggestions and comments. Special thanks to the Editor Pierre Cahuc and two anonymous reviewers for valuable comments and suggestions. The LSYPE data was provided by the Department of Education. The usual disclaimer applies. Responsible editor: Pierre Cahuc

\section{Author details}

${ }^{1}$ School of Accounting, Economics and Finance (40.215), Faculty of Business, University of Wollongong, North Wollongong, NSW 2522, Australia. ²Department of Economics, Lancaster University Management School, Bailrigg, Lancaster LA1 4YX, UK

Received: 24 June 2015 Accepted: 13 October 2015

Published online: 29 October 2015

\section{References}

Almlund M, Lee Duckworth A, Heckman JJ, Kautz T (2011) Personality Psychology and Economics. In: Hanushek EA, Machin S, Woessmann L (eds) Handbook of the Economics of Education, vol 4. Elsevier, Amsterdam, pp 1-181 Altonji JG, Elder T, Taber C (2005) Selection on observed and unobserved variables: assessing the effectiveness of catholic schools. J Polit Economy 113:151-184 
Baron JD, Cobb-Clark D (2010) Are Young People's Educational Outcomes Linked to their Sense of Control? IZA Working Paper no. 4907

Bell D, Blanchflower D (2010) Underemployment in the UK in the Great Recession. Natl Inst Econ Rev 214:R3-R25 Berger LM, Hill J, Waldfogel J (2005) Maternity leave, early maternal employment and child health and development in the US. Econ J 115:29-47

Britton J, Gregg P, Macmillan L, Mitchell S (2011) The Early Bird... Preventing Young People from becoming a NEET statistic, Report commissioned by Praxis

Caliendo M, Cobb-Clark D, Uhlendorff A (2015) Locus of control and job search strategies. Rev Econ Stat 97:88-103

Carneiro P, Heckman JJ (2003) Human Capital Policy. In: Heckman JJ, Krueger AB, Friedman BM (eds) Inequality in America: What role for human capital policies? MIT Press, Cambridge, Mass

Carneiro P, Crawford C, Goodman A (2007) The Impact of Early Cognitive and Non-Cognitive Skills on Later Outcomes, CEE DP 92

Carton J, Nowicki S (1994) Antecedents of individual differences in locus of control of reinforcement- a critical review'. Genetic Social and General Psychology 120(1):31-81

Cattaneo MD (2010) Efficient semiparametric estimation of multi-valued treatment effects under ignorability. J Econometrics 155:138-154

Cebi M (2007) Locus of control and human capital investment revisited. J Human Res 42:919-932

Chamorro-Premuzic T, Furnham A (2003) Personality predicts academic performance: evidence from two longitudinal university samples. J Res Pers 37:319-338

Chatterji P, Alegria M, Takeuchi D (2011) Psychiatric disorders and labor market outcomes: evidence from the national comorbidity survey-replication. J Health Econ 30:858-868

Cobb-Clark D, Schurer S (2012) The stability of the big-five personality traits. Econ Lett 115:11-15

Cobb-Clark D, Schurer S (2013) Two economists' musings on the stability of locus of control. Econ J 123:358-400

Cobb-Clark D, Tan M (2011) Noncognitive skills, occupational attainment, and relative wages. Lab Econ 18:1-13

Cobb-Clark D, Kassenboehmer SC, Schurer S (2014) Healthy habits: the connection between diet, exercise, and locus of control. J Econ Behav Org 98:1-28

Coleman M, DeLeire T (2003) An economic model of locus of control and the human capital investment decision. J Human Res 38:701-721

Cornaglia F, Crivellaro E, McNally S (2015) Mental health and education decisions. Lab Econ 33:1-12

Crawford C, Duckworth K, Vignoles A, Wyness G (2010) Young People's Education and Labour Market Choices Aged 16/17 to 18/19. Department of Education. Research Report DFE-RR182.

Crede M, Bashshur M, Niehorster S (2010) Reference group effects in the measurement of personality and attitudes. J Pers Assess $92: 1-10$

Dehejia RH (2005) Practical propensity score matching: a reply to smith and Todd. J Econometrics 125:355-364

Dehejia RH, Wahba S (2002) Propensity score-matching methods for non-experimental causal studies. Rev Econ Statist 84:151-161

Delaney L, Harmon C, Ryan M (2013) The role of noncognitive traits in undergraduate study behaviours. Econ Educ Rev 32:181-195

Department for Education (2011) LSYPE User Guide to the datasets: Wave 1 to Wave 7. Data Archive Study Number 5545, UK Department for Education (2014) NEET Quarterly Brief - April to June 2014. Statistical First Release

Drago F (2011) Self-esteem and earnings. J Econ Psych 32:480-488

Duckworth AL, Peterson C, Matthews MD, Kelly DR (2007) Grit: Perseverance and passion for long-term goals. J Pers Soc Psychol 92:1087-1101

Duckworth AL, Kirby T, Gollwitzer A, Oettingen G (2013) From fantasy to action. Mental Contrasting With Implementation Intentions (MCII) improves academic performance in children. Soc Psychol Personal Sci 4:745-753

Ermisch J, Francesconi M, Pevalin DJ (2001) Outcomes for children of poverty. (Research Report 158). Department for Work and Pensions, Leeds

Eskreis-Winkler L, Duckworth AL, Shulman E, Beale S (2014) The grit effect: Predicting retention in the military, the workplace, school and marriage. Front Psychol 5:36

Fletcher JM (2013) The effects of personality traits on adult labor market outcomes: Evidence from siblings. J Econ Behav Org 89:122-135

Goodman A, Sianesi B (2005) Early education and children's outcomes: how long do the impacts last? Fisc Stud 26:513-548

Gregg P (2001) The impact of youth unemployment on adult unemployment in the NCDS. Econ J 111:626-653

Groves MO (2005) How important is your personality? Labor market returns to personality for women in the US and UK. J Econ Psych 6:827-841

Gutman LM, Schoon I (2013) The impact of non-cognitive skills on outcomes for young people, Literature review, Institute of Education report for Department of Education

Hallam S, Rhamie J, Shaw J (2006) Evaluation of the Primary Behaviour and Attendance Pilot, Research Report RR717. DfES Publications, Nottingham

Heckman JJ, Masterov D (2007) The productivity argument for investing in young children. Rev Agr Econ 29:446-493

Heckman JJ, Rubinstein Y (2001) The importance of noncognitive skills: lessons from the GED testing program. Amer Econ Rev 91:145-149

Heckman J, Ichimura H, Todd P (1998) Matching as an econometric evaluation estimator. Rev Econ Stud 65:261-294

Heckman JJ, Stixrud J, Urzua S (2006) The effects of cognitive and noncognitive abilities on labor market outcomes and social behavior. J Lab Econ 24:411-482

Heckman JJ, Moon SH, Pinto R, Savelyev PA, Yavitz A (2010) The rate of return to the highscope perry preschool program. J Public Econ 9:114-128

Heine SJ, Buchtel E, Norenzayan A (2008) What do cross-national comparisons of personality traits tell us? Psych Sci 19:309-313

Johnston D, Schurer S, Shields M (2013) Exploring the intergenerational persistence of mental health: evidence from three generations. J Health Econ 32:1077-1089 
Kulas H (1996) Locus of control in adolescence: a longitudinal study. Adolesc 31:721-729

Lundberg S (2013) The college type: personality and educational inequality. J Lab Econ 31:421-441

Machin S, Manning A (1999) The causes and consequences of long-term unemployment in Europe. Handbook of Labor Economics 3(3):3085-3139

Macmillan L (2013) The role of non-cognitive and cognitive skills, behavioural and educational outcomes in accounting for the intergenerational transmission of worklessness, Institute of Education. Department of Quantitative Social Science, University of London, Working Paper 13-01

McGee A, McGee P (2011) Search, Effort, and Locus of Control. IZA Discussion Paper 5948.

Mendolia S, Walker I (2014a) The Effect of Non-Cognitive Traits on Health Behaviours in Adolescence. Health Econ 23: $1146-1158$

Mendolia S, Walker I (2014b) The effect of personality traits on subject choice and performance in high school: Evidence from an English cohort. Econ Educ Rev 43:47-65

Mroz T, Savage T (2006) The long-term effects of youth unemployment. J Human Res 41:259-293

Moffitt TE, Arseneault L, Belsky D, Dickson N, Hancox R, Harrington H, Houts R, Poulton R, Roberts BW, Ross S, Sears M, Thomson Caspi A (2011) A gradient of childhood self-control predicts health, wealth, and public safety. Proceedings of the National Academy of Sciences.

Nyhus EK, Pons E (2005) The effects of personality on earnings. J Econ Psych 26:363-384

OECD (2014) Education at a Glance 2014: OECD Indicators, OECD Publishing. http://dx.doi.org/10.1787/eag-2014-en.

Piatek R, Pinger P (2010) Maintaining (Locus of) Control? Assessing the Impact of Locus of Control on Education Decisions and Wages. IZA Discussion Paper 5289.

Rotter J (1966) Generalized expectancies for internal versus external control of reinforcement. Psycholl Monogr 80:1-28

Rosenbaum P, Rubin D (1983) The central role of the propensity score in observational studies for causal effects. Biometrika70: 41-55

Rubin D (2001) Using propensity scores to help design observational studies: application to the tobacco litigation. Health Serv Outcomes Res Methodol 2:169-188

Rubin D, Thomas N (2000) Combining propensity score matching with additional adjustments for prognostic covariates. J Am Stat Assoc 95:573-585

Ruhm CJ (2008) Maternal employment and adolescent development. Lab Econ 15:958-983

Schurer S (2014) Bouncing back from health shocks: Locus of control, labour supply, and mortality. IZA Discussion Paper 8203.

Smith J, Todd P (2004) Does matching overcome lalonde's critique of nonexperimental estimators. J Econometrics 125:305-353

Van Reenen J, Petrongolo B (2010) Jobs and youth unemployment: it's bad, but not as bad as you might think, CEP Election Analysis, CEPEA012. The London School of Economics and Political Science, Center of Economic Performance, London, UK

Wooldridge JM (2007) Inverse probability weighted estimation for general missing data problems. J Econometrics 141:1281-1301

Wooldridge JM (2010) Econometric Analysis of Cross Section and Panel Data, 2nd edn. MIT Press, Cambridge, Ma

\section{Submit your manuscript to a SpringerOpen ${ }^{\circ}$} journal and benefit from:

- Convenient online submission

- Rigorous peer review

- Immediate publication on acceptance

- Open access: articles freely available online

- High visibility within the field

Retaining the copyright to your article 